\title{
A PRELIMINARY SURVEY OF FOLIAR SCLERENCHYMA IN NEOTROPICAL LORANTHACEAE
}

\author{
J. KUIJT \& D. LYE \\ Department of Biology, University of Victoria, Victoria, BC V8W 3N5, Canada
}

\begin{abstract}
SUMMARY
The foliar sclerenchyma of all genera of neotropical Loranthaceae is surveyed by means of cleared leaves, using selected species. Three general categories of sclerenchyma are recognized. Fibers may form discontinuous or continuous bundles associated with veins or, more rarely, occur as individual cells. Sclereids, often of the astrosclereid type, are present in varying concentrations, or may be absent. Cristarque cells are very common, and occasionally extremely abundant, but are lacking in several genera. The survey includes information on terminal tracheids which are almost invariably present. Attention is drawn to the systematic significance of sclerenchyma where warranted.
\end{abstract}

Key words: Neotropical Loranthaceae, cristarque cells, fibers, sclereids, terminal tracheids.

\section{INTRODUCTION}

The Loranthaceae of the New World form an assemblage distinct from those of the Old World, none of the genera of either region occurring in both. In fact, even the relationships of genera from one hemisphere to the other have remained enigmatic. The solitary exception to this pattern is the trio of monotypic, undoubtedly primitive genera Atkinsonia, Nuytsia, and Gaiadendron, the first two of which are narrow endemics in eastern and western Australia, respectively, while the last genus ranges from Bolivia mostly through the Andes north to Costa Rica and Nicaragua.

Within the neotropical assemblage of genera, relationships are frequently also uncertain. There is general agreement on some generic affinities: for example, Dendropemon and Phthirusa, and Aetanthus and Psittacanthus, form two such closely related pairs of genera. However, the diversity of inflorescence types, anther morphology, and chromosome numbers among all these genera is very great, leaving their mutual affinities unclear in most instances. (Barlow \& Wiens, 1971; Kuijt, 1981).

The present study poses the question whether the diversity of leaf sclerenchyma in neotropical Loranthaceae might contribute to an understanding of generic relationships. An earlier paper on Oryctanthus (Kuijt, 1961) revealed such characteristics regarded of diagnostic value for that genus, and subsequent pilot projects in other genera gave considerable encouragement to this type of study. Very little is known about this aspect of Loranthaceae; Rao's (1991) compilation reveals a dearth of information for the family.

The usefulness of the information presented is necessarily limited by the accuracy of the identification of source material. Vouchers are cited for all species described and are deposited in the mistletoe herbarium presently at the University of Victoria (LEA) or other herbaria, the acronyms of which are cited in the Appendix. Since taxo- 
nomic monographs of Dendropemon and Psittacanthus are in progress, nomenclatural emendations of some of our collections may eventually be needed. The same is true for Phthirusa and Struthanthus, taxonomic treatments for which do not exist. Identifications in the other genera are probably reliable.

\section{TAXONOMY}

At present, 16 genera of neotropical Loranthaceae are recognized. They are roughly divisible into small-flowered genera and large-flowered ones, as listed below (the number in brackets indicates the approximate or estimated number of species).

\begin{tabular}{cc} 
Small-flowered genera & Large-flowered genera \\
\hline Cladocolea $(32)$ & Aetanthus $(8)$ \\
Dendropemon $(35)$ & Desmaria $(1)$ \\
Ixocactus $(8)$ & Gaiadendron $(1)$ \\
Oryctanthus $(14)$ & Ligaria $(2)$ \\
Oryctina $(8)$ & Notanthera $(1)$ \\
Panamanthus $(1)$ & Psittacanthus $(120)$ \\
Phthirusa $(30)$ & Tripodanthus $(3)$ \\
Struthanthus $(60)$ & Tristerix $(11)$
\end{tabular}

The genera of large-flowered species have been essentially stable taxonomically since Eichler's (1868) work even though the largest one, Psittacanthus, has not yet been monographed. Such stability is not the case, however, for the small-flowered genera in which, with the exception of Dendropemon and Oryctanthus, significant changes in generic status and delimitations have occurred in the past two or three decades. A perennial problem in several of those genera is the greatly crowded and condensed condition of exceedingly small inflorescences, bearing the smallest flowers in Loranthaceae; in some, inflorescences are absent. Thus the analysis of inflorescence structure is sometimes very difficult; in several crucial species, the available material is very limited as the species are rare. Especially Phthirusa at present appears to be a heterogeneous taxon, while Struthanthus is believed to be polyphyletic (Kuijt, 1975). Cladocolea has turned out to be much more complex than first envisaged in Kuijt (1975).

A clear subfamilial framework for the neotropical genera is, unfortunately, not available at present. Engler \& Krause (1935) constructed an elaborate system but, while elements of it remain useful, its broad outlines for the New World are no longer acceptable. There is some palynological evidence that the small-flowered genera as listed above form a natural group (Feuer \& Kuijt, 1985). That this is so for the largeflowered group is less clear; certainly the karyological evidence is not convincing (Barlow \& Wiens, 1971), and the group is palynologically extremely diverse (Feuer \& Kuijt, 1979a, b).

In all probability, the Loranthaceae of the Old World also constitute an untapped reservoir of sclerenchyma diversity with potential implications for taxonomic affinities. For example, a preparation of the leaves of Amyema pendula (Spreng.) Tiegh. from Australia has shown us the presence of innumerable, long-armed astrosclereids throughout the leaf as well as clusters of terminal tracheids; cristarque cells and fibers, however, 
are absent in that species. Rao \& Kelkar (1951) have reported the existence of both terminal and non-terminal astrosclereids in the leaves of various species of Loranthus. (It should be noted that the species there referred to belong to at least 7 different genera following Danser, 1933). A few additional details for the family are summarized by Solereder (1899). A parallel study of palaeotropical Loranthaceae might provide new information on the relationships among those genera, and conceivably have a bearing on their affinities to genera of the New World.

\section{Terminology: the categories of foliar sclerenchyma}

In 1991, Rao published a comprehensive summary of foliar sclerenchyma in angiosperms, excluding what he called bast fibers. Part of his presentation consisted of an elaborate hierarchy of cell types, including numerous new terms, to accommodate the extremely variable form these cells can assume in different angiosperm taxa. In our present study, we prefer not to use Rao's elaborate terminology. In several instances we have encountered sclerenchyma types which are not present in Rao's account, and we had little choice but to coin descriptive terms for those. It should be pointed out also that Rao's employment of the word 'sclereid' is substantially different from its use in such standard plant anatomy texts as Fahn (1967), Esau (1977), and Dickison (2000), where application of the term is grounded on its typically not much elongated shape. Rao's use of the term is not so much based on shape as the cell's lack of physical and/or ontogenetic separateness from procambial or mature vascular strands. For example, he uses the term for unbranched, slender, undulate cells which develop in the mesophyll of Linociera malabarica Wall. (= Chionanthus; Oleaceae; see his fig. 3.2.J). Nor is Rao entirely consistent in his application of the term, as some cell types included in his survey are invariably connected to vascular strands, especially the terminal sclereids. It is also curious that he ignored a category which at least in Loranthaceae is very important, viz. cristarque cells. We prefer to follow the simpler, morphology-based sclerenchyma designations of Esau and others, and of necessity need to include those sclerenchyma elements which are related to the vascular reticulum (bast fibers or extraxylary fibers and cristarque cells); to not do so in our taxa would ignore some of the most striking cell types.

The cells which are relevant in our study are of four basic types, as briefly circumscribed below.

1) Fibers - Long, unbranched filiform cells with thick secondary walls, commonly associated with subterminal and larger portions of the leaf veins. In such positions, they are often difficult to separate visually from the veins themselves. They may protrude slightly from the veins or, occasionally, may lie parallel to them nearby. A special form is seen in the serpentine fibers mentioned below only for Notanthera heterophylla (Ruiz \& Pav.) G. Don.

2) Sclereids - More or less isodiametric cells with extremely heavy secondary walls traversed by simple pits. Two subcategories are recognized:

a) astrosclereids (Fig. 7B-D) which are star-shaped cells, with arms extending from a central body, occurring either singly or in clusters in leaf mesophyll or associated with vein endings; and

b) brachysclereids (Fig. 6C) which tend to be smaller, lack arms, and which may accompany veins but only rarely at their endings. 
Where sclereids are clustered at the terminus of vein endings they may also be referred to as terminal sclereids, denoting position rather than shape. Terminal sclereids have not been observed in the present study, but are reported in some palaeotropical species (Rao \& Kelkar, 1951). The sclereids of Ligaria (Fig. 4D) correspond to Rao's columnar ramiform sclereids as illustrated for Linociera macrocarpa (King) Gamble (Rao, 1991, fig. 3.2.H).

3) Cristarque cells - Crystalliferous sclereids, mostly in the shape and distribution of brachysclereids, but each containing a single calcium oxalate crystal, the cell wall thickening eccentrically. In the most common type, the single, cubical or
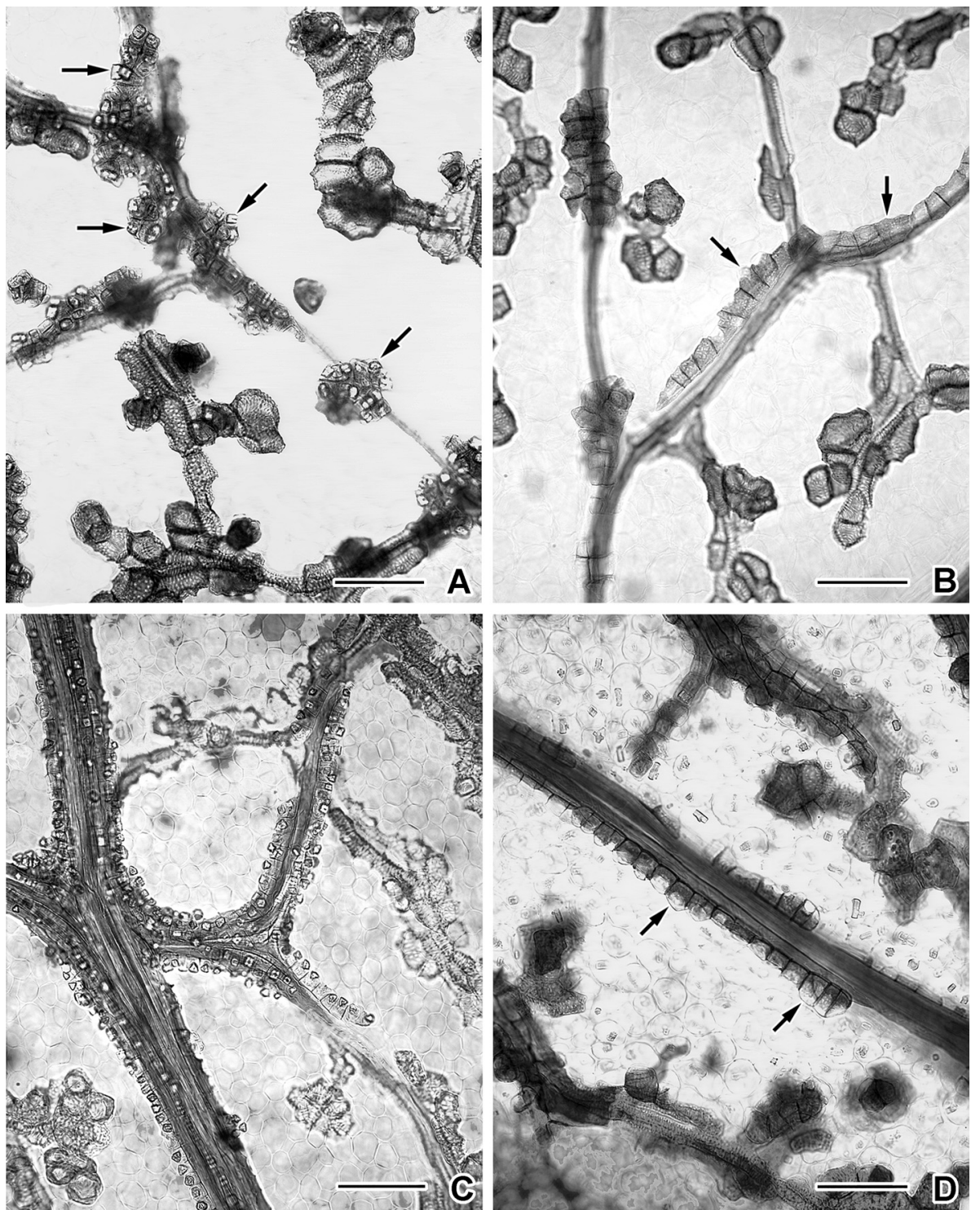
rhombic crystal nearly fills the remaining cell lumen; in a more unusual type, the crystal appears as a rounded button protruding from the cell's surface (Struthanthus matudai Lundell, Fig. 1D). At least in the plants here considered, they tend to occur in linear arrangements or clusters along veins (Fig. 1B, D), especially larger ones; in Oryctanthus occidentalis (L.) Eichler, clusters of cristarque cells are present throughout the mesophyll. In rare instances, vein endings have a mixture of terminal tracheids and cristarque cells (e.g., Phthirusa lepidobotrys Eichler and several species of Dendropemon). In a single species (Oryctanthus occidentalis), cells have been noted that are intermediate to sclereids.

4) Terminal tracheids - Short and wide, angular to rounded, blunt tracheary elements clustered at the tip of vein endings, and provided with unusually large pits or, more rarely, prominent scalariform wall thickenings; often called 'storage tracheids', a possibly misleading term first introduced by Heinricher (1885). Our impression is that terminal tracheids resembling normal, nearby tracheids tend to have a more scalariform pitting, others being more normally pitted. It is perhaps debatable whether this cell type may be called sclerenchyma, as it may be transitional to xylem, but the conspicuous presence in most genera warrants inclusion in our survey; moreover, Rao's (1991) treatment includes such cells in sclerenchyma. Terminal tracheids occur in very small groups, or even singly, and transitional tracheary cells to the normal tracheary elements of the veinlets are frequently present subterminally. It is believed that some terminal tracheids are dead while others contain living protoplasts (Pirwitz, 1931, Napp-Zinn, 1973). Sherwin Carlquist (Santa Barbara) has suggested that the term 'storage tracheid' may not be entirely inappropriate, given the somewhat xerophytic condition of parasitic mistletoes, however, we prefer a topographical term rather than one of undocumented physiological meaning. In Rao's account, the term 'terminal sclerotracheid' is used, while Rao \& Das (1979) employ 'tracheoid' and Rao \& Mody (1961) 'tracheoidal idioblast'.

\section{Additional terms}

Free veinlets - The portions of the leaf skeleton, simple or somewhat branched, which terminate freely in the leaf mesophyll of an areole.

Intermediate veins - Those parts of the minor vascular skeleton which lie between the major lateral veins and the free veinlets.

Major lateral veins - The large lateral veins issuing directly from the midrib.

Stellate fiber bundles - Bundles (simple or branched) of simple fibers which together cover a limited portion of the intermediate vein reticulum. Fig. 5C-F.

Transitional elements - Tracheary elements intermediate in shape and size between those of the reticulum and the terminal tracheids; secondary walls have scalariform to annular pits.

Fig. 1. Representative illustrations of sclerenchyma types. - A. Cristarque cells of the clustered type (arrows) (Dendropemon caribaeus, Ricksecker 313); B. cristarque cells of the serial type (arrows) (Dendropemon uniflorus, Leonard \& Leonard 15026); C. cristarque cells forming a sheath around veins (Gaiadendron punctatum, Dodson \& Thien 1521); D. cristarque cells with rounded crystals (arrows) (Struthanthus matudai, Matuda 1808). - Scale bar $=100 \mu \mathrm{m}$. 


\section{MATERIALS AND METHODS}

The information provided in this study is based on observations from cleared and stained leaves obtained from herbarium specimens. Leaves were placed in $10 \% \mathrm{NaOH}$ at room temperature, changing the solution upon discoloration until the leaves became opaque; the $5 \%$ solution commonly used was not sufficiently rapid. Some species cleared relatively quickly, others required from 2 to 6 months or even longer; yet others could not be cleared at all. The (very fragile) specimens were then thoroughly washed in at least 3 changes of distilled water, taking care to minimize turbulence around the sample, and placed in aqueous chloral hydrate $(250 \mathrm{~g} / 100 \mathrm{ml}$ distilled water). Successfully cleared leaves appeared transparent after 2 to several days, after which specimens were carefully washed with water and dehydrated through a graduated ethanol series to $100 \%$ ethanol (if leaves remained cloudy, they were again washed in water and returned to $10 \% \mathrm{NaOH}$ for further clearing). Ethanol rendered the leaves quite rigid, allowing them to be readily cut into portions suitable for staining and mounting; small leaves were mounted whole. Specimens were stained for 15 minutes in safranin O (1\% in $100 \%$ ethanol), destained while visually monitored in $100 \%$ ethanol, followed by a solution of equal parts of Hemo D (a xylene substitute) and ethanol. After destaining, specimens were immersed in Hemo D for 15 minutes and mounted in Histoclad, Entellan, or Cytosol 280. The above protocol represents a combination of methods outlined by Foster (1950), Lersten (1967), and Berlyn \& Miksche (1976). Since Hemo D melts plastic dishes, glass must be used. Our observations were made with light microscopes and, in some cases, checked under polarized light.

There are some facets of leaf architecture which cannot be adequately dealt with following our procedures. Ideally, a developmental study might clarify whether juvenile and mature leaves differ in the matter of sclerenchyma; it is possible that some forms of sclerenchyma differentiate late. Care was taken throughout our study to select mature leaves. While it is unlikely that host species influence the leaf structure of mistletoes, this factor again cannot be automatically dismissed. It is certain that, at least in some species, significant sclerenchyma differences exist between leaf tips and margins versus the base and petiole (see, for example, the sclereids of Oryctina atrolineata, Fig. $5 \mathrm{~F}$ ). A full survey would, for each species, specify such differences. Finally, there is evidence of intraspecific sclerenchyma variation in some species. The most clearly established case of such variation is seen in Gaiadendron punctatum, as detailed below. In Struthanthus leptostachyus, no sclereids were observed in one instance (A.43) while they were abundant in three others (A.19, A.26, A.97). It is impossible to say from our data what the nature of such variation is.

Although even a casual inspection of material shows that significant size differences exist between sclerenchyma cells of many taxa, a meaningful comparative tabulation of data has proven impossible. This difficulty is due partly to the variation within a leaf, partly to the three-dimensional shape of especially the astrosclereids, where few arms are in a useful optical plane. In some cases, even the arms on a single astrosclereid vary in length, as in Struthanthus condensatus. Where sclereids occur in clusters, it is usually impossible to separate them visually. In Ligaria, the main body of the sclereids is mostly perpendicular to the leaf surface, and transverse sections would be required for measurements. It is hoped that the micrographs will be adequate for the purposes of comparison. 


\section{RESULTS}

It is scarcely surprising that the leaves of different taxa have reacted variously to the clearing treatment we employed. Such variation is partly due to the differences in thickness of leaves, but chemical differences must play a part. As stated above, some leaves cleared very quickly, but in other instances even months in $\mathrm{NaOH}$ failed to dislodge pigments, making observations difficult or incomplete. In some species, the epidermis seems to have rather massive cell walls, interfering with optical resolution of the interior of the blade. The age element may also be important: young leaves may be easier to clear, but sclerenchyma differentiation may then not yet be complete.

\section{AETANTHUS - Fig. 2A}

Fibers - Absent, except an occasional one on intermediate veins of A. macranthus.

Sclereids - Profuse astrosclereids in A. aff. andreanus; present in A. macranthus; absent in A. nodosus.

Cristarque cells - Absent.

Terminal tracheids - Few but well developed in A. aff. andreanus and A. macranthus, but poorly differentiated in A. nodosus.

Comments - The species sampled are too few in number to allow any definitive statement on the genus. Aetanthus aff. andreanus and A. macranthus and one sample of A. nodosus are characterized by clustered, very short-armed astrosclereids, but another collection of the last species lacks sclerenchyma of any sort. As in the closely related Psittacanthus, a constant feature is the absence of cristarque cells. The leaf skeleton is very delicate throughout.

Species studied:

Aetanthus aff. andreanus, A. macranthus, A. nodosus (Fig. 2A).

\section{CLADOCOLEA - Fig. 2B-D}

Fibers - Absent or nearly so in apparently all species except $C$. nitida, where a dense sheath of fibers surrounds all veins except the veinlets, their tips often extending sideways like small spurs (Fig. 2C).

Sclereids - In C. archeri, astrosclereids, with a few short, blunt to pointed arms, are present and located mostly near the largest veins. Smaller clusters of the same type of cell may be seen in C. alternifolia, $C$. archeri, $C$. coriacea, $C$. peruviana, $C$. primaria, and $C$. pringlei. In the other three species, sclereids are absent $(C$. loniceroides, C. microphylla, $C$. nitida). In C. roraimensis, the density of sclereids is such that all other anatomical features are completely obscured (Fig. 2D).

Cristarque cells - Present in C. coriacea, but apparently not in any other species studied.

Terminal tracheids - Present in all species studied, with transitional elements; angular and few in C. loniceroides, and not always distinguishable from nearby xylary elements; veins sometimes nearly encased in broad or linear transitional elements; strongly angular in $C$. nitida, with similar encasing elements. 
Comments - As in most other genera of this survey, much structural divergence has evolved in foliar anatomy, especially in the occurrence of sclereids. Cristarque cells and fibers are absent in nearly all species studied.

Species studied:

Cladocolea alternifolia, C. archeri (Fig. 2B), C. coriacea, C. cupulata, C. loniceroides, C. microphylla, C. nitida (Fig. 2C), C. peruviana, C. primaria, C. pringlei, C. roraimensis (Fig. 2D).
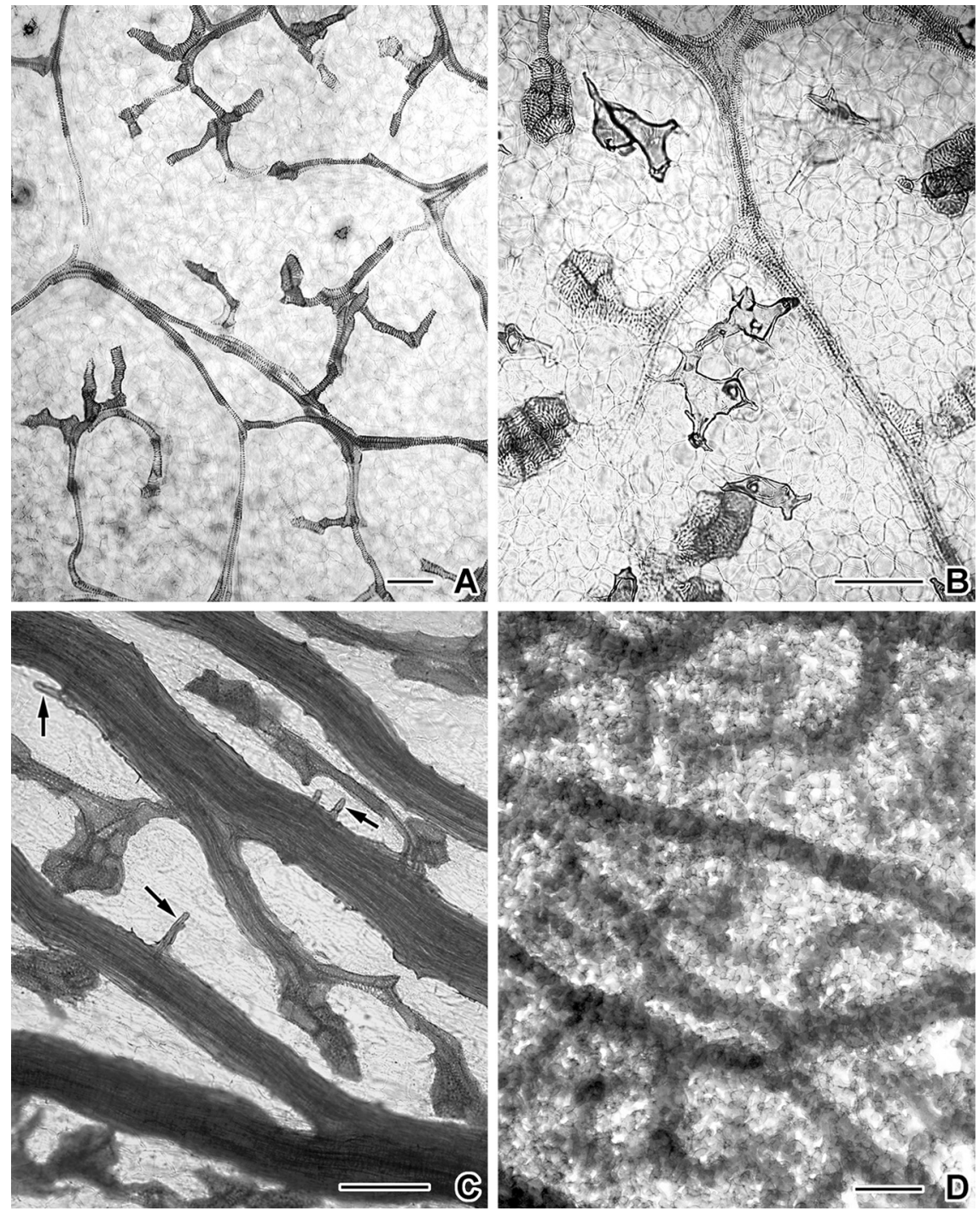

Fig. 2. Aetanthus and Cladocolea. - A. Aetanthus nodosus: absence of sclerenchyma except for weakly developed terminal tracheids, and lack of cristarque cells (Macbride 4900); B. Cladocolea archeri: thin-walled astrosclereids (Fagerlind \& Wibom 1758); C. Cladocolea nitida: massive fiber bundles with fiber spurs (arrows) (Henkel et al. 4400); D. Cladocolea roraimensis: dense astrosclereids obscuring venation (Steyermark 58943). - Scale bar $=100 \mu \mathrm{m}$. 


\section{DENDROPEMON - Fig. 1A, B, 3A-D}

Fibers - None observed.

Sclereids - None observed with certainty.

Cristarque cells - All species showed cristarque cells, in linear series and/or in clumps of various sizes, sometimes completely encasing the vein. In D. rostratus and D. sessiliflorus, these clumps were mostly associated with large veins, the smaller veins being largely without. Crystals are very small in $D$. uniflorus. In at least three species (D. pauciflorus, D. purpureus, and D. pycnophyllus) cristarque cells are present both along veins and among terminal tracheids at the vein endings.

Terminal tracheids - Present in all specimens studied, in small or larger clusters; some are slender, others quite large and broad. In D. sessiliflorus, the clumps may nearly fill the areole; in contrast, terminal tracheids are sometimes few in D. alatus.

Comments - In D. alatus, some of the mesophyll areas between projecting clusters of terminal tracheids contain single clusters of very dense-staining cells which may or may not be sclerified. The individual cells are united around a common center and are convex to the outside. Our methods do not allow certainty as to whether secondary walls are present, but this seems doubtful. No other Dendropemon species appeared to develop such structures. There is some question as to the presence of brachysclereids in the mesophyll of $D$. purpureus, but our material was inconclusive.

Species studied:

Dendropemon alatus (Fig. 3C), D. bistriatus, D. brachycarpus, D. caribaeus (Figs. 1A, 3D), D. constantiae, D. emarginatus (Fig. 3B), D. parvifolius, D. pauciflorus, D. picardae, D. psilobotrys, D. purpureus, D. pycnophyllus (Fig. 3A), D. rostratus, D. sessiliflorus, D. uniflorus (Fig. 1B).

\section{DESMARIA MUTABILIS - Fig. 3E}

Fibers - None observed.

Sclereids - None observed.

Cristarque cells - None observed.

Terminal tracheids - Small clumps of more or less isodiametric cells, weakly developed, with transitional ones to regular tracheary elements. Transitional cells often appear to encase the veinlets.

Comments - The genus seems remarkable in its total absence of any form of true sclerenchyma.

It was suggested some years ago (Kuijt, 1985) that the south-Chilean, endemic monotypic genera Desmaria and Notanthera might be related to the more northerly, also monotypic genus Gaiadendron. Leaf anatomy, however, provides no support for this notion, the three genera having virtually no relevant features in common. The anatomical uniqueness of Notanthera is detailed below.

The anatomical simplicity of the Desmaria leaf may well be related to the deciduous nature of the species (Kuijt, 1985), perhaps unique in the New World (but see Psittacanthus palmeri, below). All other South American Loranthaceae have perennial leaves which thus face a much longer functional life, sometimes encompassing one or more dry seasons. 


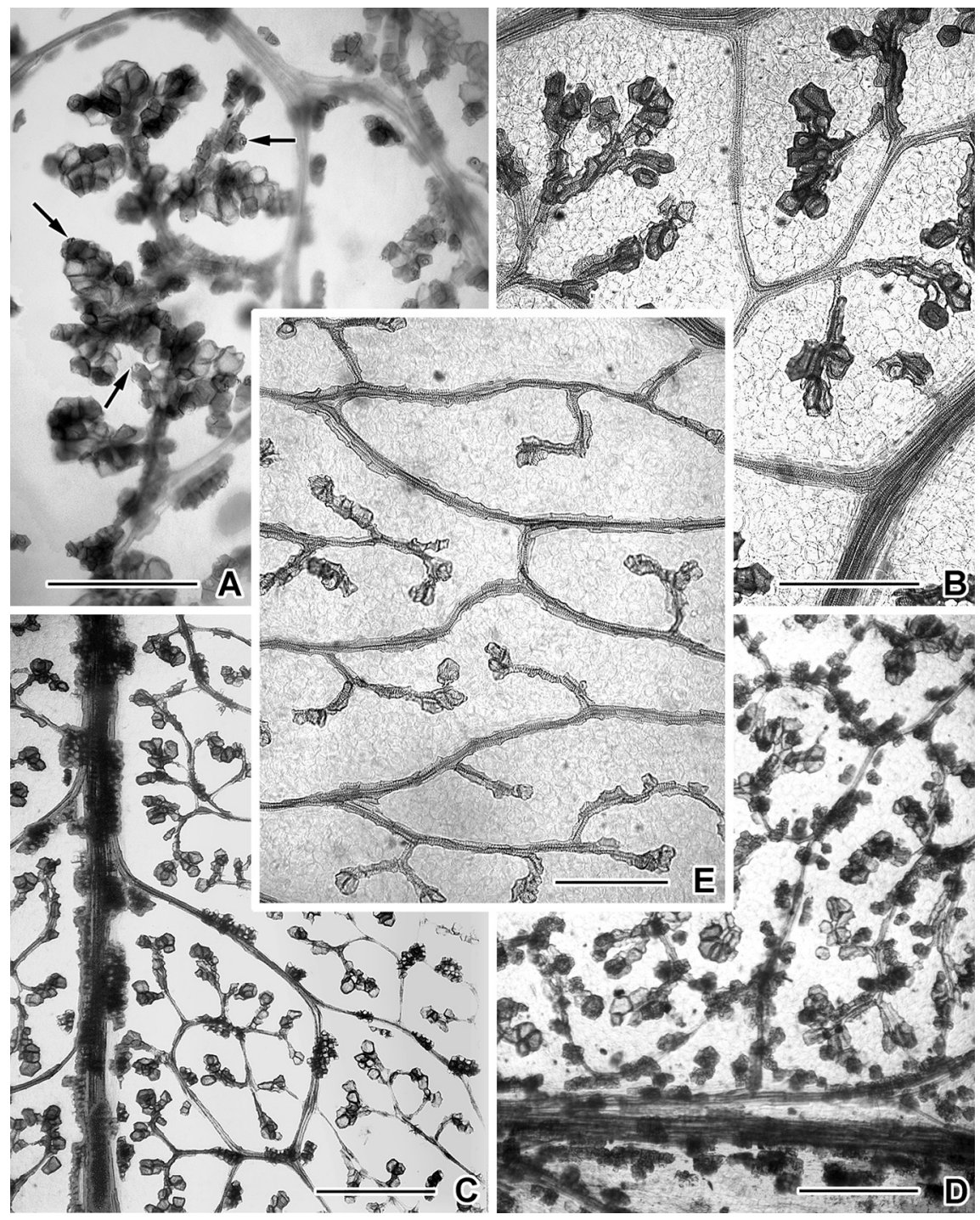

Fig. 3. Dendropemon and Desmaria. - A. Dendropemon pycnophyllus: clumped terminal tracheids mixed with cristarque cells (arrows), and small cristarque cell series along smaller veins (Howard \& Howard 9051); B. Dendropemon emarginatus: large terminal tracheids; absence of cristarque cells (Sintenis 4401); C. Dendropemon alatus: large clumps of cristarque cells along midvein, small ones along intermediate veins (Leonard 4070); D. Dendropemon caribaeus: clumps of cristarque cells along all veins (Ricksecker 313); E. Desmaria mutabilis: absence of sclerenchyma; weakly developed terminal tracheids (Eyerdam 10192). - Scale bar $=250 \mu \mathrm{m}$.

A comparison between Desmaria and Psittacanthus palmeri, both of which have thin leaves with simple venation lacking any sclerenchyma, suggests that there may be some correlation between deciduousness and anatomical structure. In the former case, it has been established (Kuijt, 1985) that the species is deciduous, a feature which in 
Loranthaceae is known to be shared only with Loranthus europaeus. Psittacanthus palmeri also seems to be seasonally deciduous. A more general view, however, seems to indicate that the correlation really is of a geographic or climatic nature: this type of simplicity tends to be found typically in the lowest latitudes, on the northern and southern borders of the family's geographic range. The additional examples from our survey which could be added are Struthanthus uruguensis and Tripodanthus flagellaris. We add photographs of the leaf structure of Loranthus europaeus and Tupeia antarctica from New Zealand (Fig. 9E, F). All four of these species show a foliar anatomy essentially comparable to that of Desmaria and Psittacanthus palmeri. The entire genus Tristerix, certainly of southern origin, might also fit this pattern even though some species are presently of a tropical preference, often at high elevations. Admittedly, the extraordinary leaf structure of Notanthera would seem to be an exception to this geographical pattern, as is the simple foliar skeleton of Psittacanthus gigas from the Colombian Pacific lowland.

\section{GAIADENDRON PUNCTATUM - Fig. 1C, 4A, B}

Fibers - None observed as fiber bundles, except sometimes as very slender ones, or as individual, scattered cells along intermediate and larger veins. In one collection, Dodson \& Thien 1332, large numbers of short, blunt, prominently pitted, short fibers form along the veins, even the smallest ones near the terminal tracheids, often with blunt ends pressing against each other (Fig. 4B). The Bolivian collection, Bang 1569, lacks fibers completely (Fig. 4A).

Sclereids - None observed.

Cristarque cells - Numerous and small, associated with, and parallel to, the midrib and at least the large veins often in short (usually uniseriate) files; in some cases so many are present that they form a sheath around the bundle (Fig. 1C). Sometimes, single files of these cristarque cells are so slender that they resemble short fibers in overall shape. No cristarque cells could be detected in Bang 1569 or Dodson \& Thien 1332 (Fig. 4A, B).

Terminal tracheids - Prominent, globose clumps of few to 10 or more, large, profusely pitted, subtended by transitional cells, in all collections studied.

Comments - The great variability in leaf anatomy of Gaiadendron punctatum makes it difficult to characterize the taxon as a whole. Three entirely different sclerenchyma configurations are present in the leaves of this monotypic genus. In a Bolivian collection, Bang 1569, the leaf skeleton is delicate and lacks any evidence of either cristarque cells or fibers (Fig. 4A). The other two collections sampled are both from Ecuador. In Dodson \& Thien 1521 all veins, including even the smallest ones, are encrusted with innumerable small cristarque cells (Fig. 1C). In Dodson \& Thien 1332, however, cristarque cells are completely absent; instead, all veins are flanked by many short, blunt, profusely pitted fibers often arranged end-to-end but not forming fiber bundles (Fig. 4B).

Thus Gaiadendron punctatum, one of the three most primitive members of Loranthaceae, emerges also as one of the most variable ones. Its flower size is extremely diverse (unpubl. inf.). The color of the corolla varies from golden yellow (nearly orange in some southern areas) to pure white in northern Andean areas. Its parasitic behavior is 
uniquely flexible, as it may grow on tree branches as well as on the ground (Kuijt, 1963, 1989). The anatomical information here supplied adds a striking aspect of variation. Clearly, G. punctatum is worthy of more detailed study throughout its extended range.

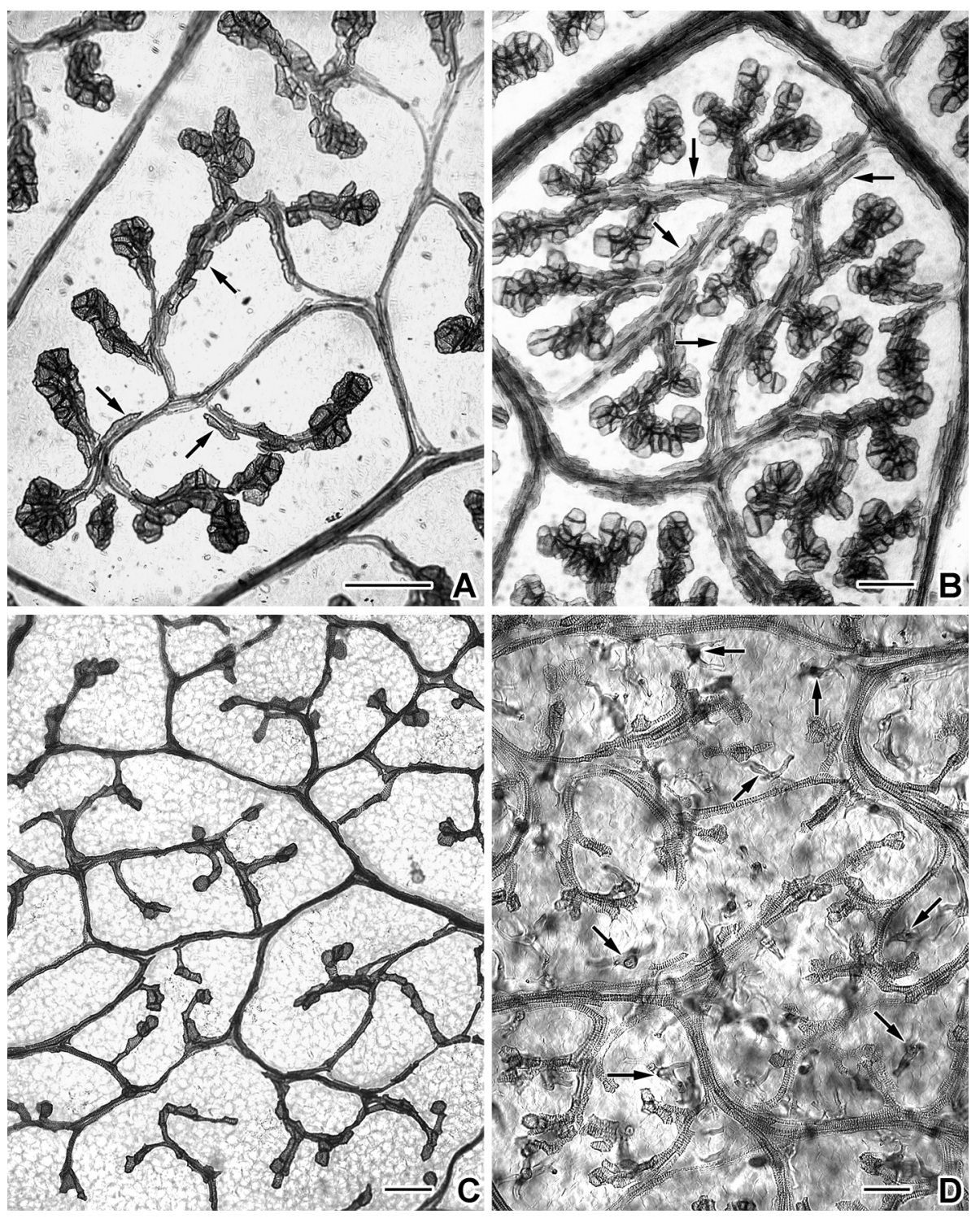

Fig. 4. Gaiadendron, Ixocactus, and Ligaria. - A. Gaiadendron punctatum: absence of cristarque cells and fibers; few and small transitional elements (arrows) (Bang 1569); B. Gaiadendron punctatum: numerous short, blunt, pitted fibers along small veins (arrows); absence of cristarque cells (Dodson \& Thien 1332); C. Ixocactus inconspicuus: absence of sclerenchyma; weakly differentiated terminal tracheids (Lott 2613); D. Ligaria cuneifolium: absence of fibers and cristarque cells; presence of columnar ramiform sclereids (arrows) (Venturi 10297). - Scale bar $=100 \mu \mathrm{m}$. 


\section{IXOCACTUS - Fig. 4C}

Fibers - None observed.

Sclereids - None observed except in I. clandestinus, where they are somewhat pear-shaped.

Cristarque cells - Large clumps near the leaf base in I. inconspicuus and I. rhynchophyllus, apparently in the position of bundle sheaths.

Terminal tracheids - Small clumps in all 5 species studied, prominently pitted.

Comments - Little can be generalized from our results except that terminal tracheids are present in all 4 species studied, although sometimes weakly developed, as in I. gracilis, I. inconspicuus, and I. rhynchanthus, and that no fibers have been seen. Only I. clandestinus showed sclereids, which are rather globular in shape and have extremely short arms. It should be noted that the taxonomic status of this species in Ixocactus is somewhat uncertain, in contrast to that of the other species studied.

Species studied:

Ixocactus clandestinus, I. gracilis, I. inconspicuus (Fig. 4C), I. inornus, I. rhynchophyllus.

\section{LIGARIA CUNEIFOLIA - Fig. 4D}

Fibers - None observed.

Sclereids - Columnar ramiform sclereids with few long, pointed, occasionally branching arms, occur apparently in two distinct layers, one above and one below the level of the veins. The crystals reportedly present in sclereid walls (see Varela \& Gurni, 1995, 1998, 1999; Fernández et al., 2000) are not evident in cleared material or under polarized light. Small groups of parallel, slanting pits are frequently visible. This type of sclereid is not known from other Loranthaceae.

Cristarque cells - None observed.

Terminal tracheids - Single cells to large clusters, with adjacent transitional elements which encase all veinlets.

Comments - The sclereid type of Ligaria is diagnostic, as is the absence of both fibers and cristarque cells. Only the common species, L. cuneifolia, was investigated. Its foliar anatomy has some unusual features. Two layers of rather sparse, individual sclereids are present corresponding to the lower and upper mesophyll. In shape, the cells may be equated with the columnar ramiform sclereids as illustrated for Linociera macrocarpa (King) Gamble (Rao, 1991, fig. 3.2.H). The elongated middle portion is unbranched while the two ends often are somewhat branched. These cells, like the osteosclereids in some angiosperms like Mouriria (Foster, 1947), are essentially perpendicular to the leaf surface. This may represent the only known instance of this type of sclereid in Loranthaceae. Neither cristarque cells nor fibers are present. Terminal tracheids do occur, either singly or in large clusters, with transitional elements often encasing the nearby veinlet. Thus, the unique leaf anatomy confirms the isolated taxonomic position of the genus (Barlow \& Wiens, 1971). It should be added that Fernandez et al. (2000) reported calcium oxalate crystals in, or associated with, Ligaria sclereids, which we have not been able to identify. Such cells, if confirmed, would not be comparable to cristarque cells. In some palaeotropical Loranthaceae, sclereids containing crystals have also been reported (Rao \& Kelkar, 1951; Rao \& Malaviya, 1962). 


\section{NOTANTHERA HETEROPHYLLA - Fig. 5A, B}

Fibers - The leaf mesophyll contains a great abundance of unbranched, serpentine fibers, each of which follows an extremely convoluted path. Many or most of the larger veins are accompanied or even surrounded by bundles of such fibers (where straight) each member of which may diverge abruptly, either individually or in small, twisted groups, sometimes following one of the smallest veinlets or pursuing an individual, highly erratic path. It is virtually impossible to follow an individual serpentine fiber from end to end. Thus, the original direction of growth cannot be ascertained from mature specimens, and we cannot be certain if only one end of the fiber elongates in this fashion. Similarly, we have no way to estimate the entire length of fibers; the longest separate portion we have been able to follow is at least 700-1000 $\mu \mathrm{m}$ in length. The terminal portion of a fiber commonly is abruptly rounded; the diameter remains the same along its entire length.

Sclereids - None observed.

Cristarque cells - None observed.

Terminal tracheids - None; veinlets terminate in one or two very slender, tapering elements.

Comments - The basic xylem reticulum seems rather delicate, and no evidence of normal fibers, sclereids, terminal tracheids or cristarque cells has been seen. Nearly all veins are accompanied by the bundled portions of serpentine fibers.

The course of an individual serpentine fiber through the mesophyll is extremely difficult to ascertain, but strongly suggests that it follows intercellular spaces, one end being associated with a vascular bundle. The other end may be lodged against a different bundle, or it may terminate freely in the mesophyll. Frequently, several fibers diverge from a bundle together to form a loose fascicle lacking vascular elements, only to become dissociated later. In the leaf margin, serpentine fibers may reach the very surface of the blade. In a few cases, the tip of a fiber has been seen to penetrate the epidermis.

The leaves of this monotypic genus are unique in our survey in that they lack sclereids, cristarque cells, and terminal tracheids but especially by the presence of a profusion of the extraordinary serpentine fibers described above. The only mention of this cell type in the scientific literature is found in a single sentence in Reiche (1907: 378), in which he briefly refers to these cells as "nicht verholzten Bastbelege der Gefässsbündel" which reach from the vein endings to form a network in the mesophyll. This brief mention is not entirely accurate: a network would require fiber portions to fuse with, or become appressed to, others, and such a network does not exist. Also, the serpentine fibers are by no means limited to vein endings; they more commonly depart from more proximal portions of the reticulum. In our view, these remarkable cells must be regarded as fibers, and have secondary walls, the bordered pits having strongly oblique apertures.

If their course, as suggested above, follows intercellular mesophyll space in their early development, their differentiation would be placed late in leaf ontogeny, in agreement with relevant statements in Dickison (2000). We have not been able to discover any comparable sclerenchyma elements in the anatomical literature (Solereder, 1899; Metcalfe \& Chalk, 1950) except possibly in Heisteria (Olacaceae) illustrated in Rao (1991, fig. 5.31) and Baas \& Kool (1983), where they are referred to as fibrosclereids 
and fibrous mesophyll sclereids, respectively. No matter how we regard these curious cells, they constitute a diagnostic anatomical feature for Notanthera. In our material, they stain with safranin, and we assume that their cell walls are sclerified at least at maturity.

In one as yet unpublished species of Psittacanthus (Roldán et al. 796, LEA), we find astrosclereids with extremely long, slender, and sinuous arms which are superficially similar to the serpentine fibers of Notanthera, but this similarity is strictly superficial.

\section{ORYCTANTHUS - Fig. 5C-E}

Fibers - Fibers are simple, thick-walled, and occur in compound, stellate bundles which branch, following subterminal portions of the venation, as earlier described (Kuijt, 1961), in all species studied. Not all such bundles are branched; in O. spicatus many are simple.

Sclereids - Absent in some O. spicatus specimens (Kuijt 2476, Gentle 1426), present in others (Kuijt 2441); present in at least O. cordifolius and O.florulentus, where they are thick-walled and profusely pitted, with very short, often round-tipped arms. In $O$. cordifolius such crystals appear to have formed on the outside of the sclereids, these cells forming numerous clusters throughout the mesophyll without reference to the veins or fiber bundles; in $O$. florulentus no crystals are associated with sclereids. Cristarque cells tend to be common on the surface of stellate fiber bundles.

Cristarque cells - Abundant, either in files along portions of the veins, on the surface of fiber bundles, or in small, angular clumps which resemble together shortarmed astrosclereids; these clusters may be distributed randomly over the surface of the stellate fiber bundles. Cristarque cells may be found throughout the lamina, but are most abundant near the major veins. Oryctanthus spicatus has significantly fewer cristarque cells than the other species studied.

Terminal tracheids - Present at all vein endings, in clumps, subtended by transitional elements.

Comments - Stellate fiber bundles represent often branching bundles of simple fibers which are of extraxylary origin, associated with subterminal portions of the intermediate reticulum. Not all such bundles are branched; in O. spicatus, many are simple. They were originally thought to be diagnostic for Oryctanthus, but our present results show this to be a misconception. It is true that all known species of Oryctanthus are characterized by such sclerenchyma, but the same type is present in several species not belonging to that genus. The most striking example is Oryctina atrolineata, but some Struthanthus species have a seemingly comparable arrangement of fibers (see below). We are here not concerned with a taxonomic misplacement, as may be seen in its inflorescence structure and floral details (Kuijt, 2003). Other somewhat comparable examples are seen in several species of Struthanthus, but those fiber bundles tend to form a more or less continuous network reflecting the veins and do not form separate, stellate units. In all these cases, fiber bundles are accompanied by clusters or series of cristarque cells, especially in Oryctanthus.

The genus is also remarkable for its diversity of sclereids. Oryctanthus spicatus may lack sclereids completely in some collections (Gentle 1426, Kuijt 2476; Fig. 5C), but 
they may be abundant in others (Kuijt 2441). Other species investigated have numerous, short-armed, profusely pitted sclereids distributed throughout the mesophyll. These are single or in very small groups in $O$. florulentus, where they do not bear crystals. In O. cordifolius, however, these sclereids bear rather large cuboidal crystals, apparently on their outside surfaces. In O. occidentalis, these clusters seem to be intermediate between

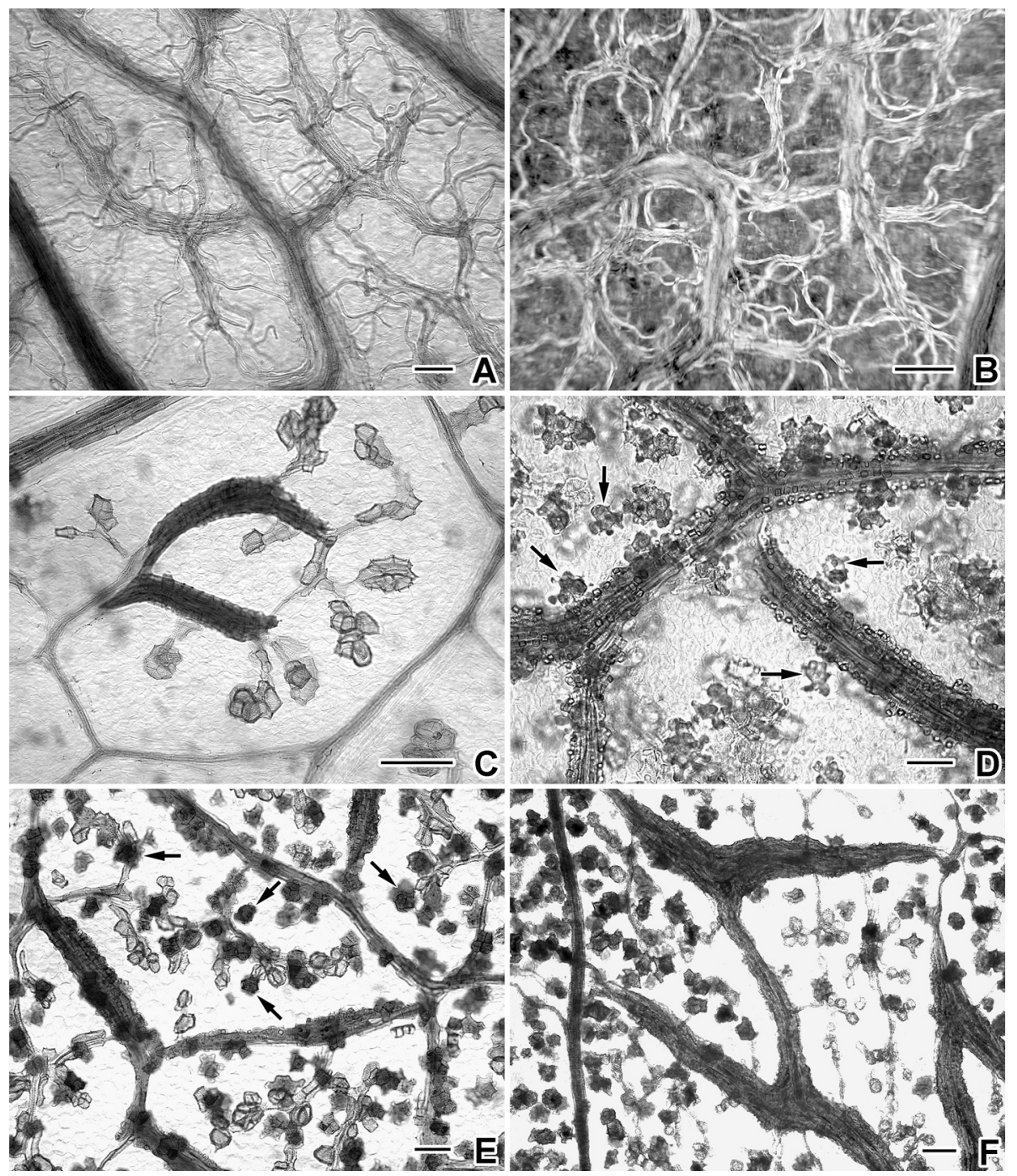

Fig. 5. Notanthera, Oryctanthus, and Oryctina. - A, B. Notanthera heterophylla: serpentine fibers, B observed under polarized light (Eyerdam 10608); C. Oryctanthus spicatus: stellate fiber bundles, terminal tracheids, and absence of other sclerenchyma (Kuijt 2476); D. Oryctanthus cordifolius: stellate fiber bundles, astrosclereids (arrows), and profuse cristarque cells (Kuijt 2571); E. Oryctanthus occidentalis: stellate fiber bundles with cristarque cells; numerous brachysclereids (arrows) (Kuijt 2413); F. Oryctina atrolineata, stellate fiber bundles and numerous astrosclereids (Pipoly \& Godfrey 7388). - Scale bar $=100 \mu \mathrm{m}$. 
cristarque cells and brachysclereids, each cell being strongly pitted and containing a cuboidal crystal. Separately, O. occidentalis also has its fiber bundles strongly encrusted with cristarque cells, as does $O$. cordifolius. The possible anatomical contrast between $O$. florulentus and $O$. spicatus is interesting in that they are believed to intergrade in the northern Andes (Kuijt, 1976).

Species studied:

Oryctanthus alveolatus, O. cordifolius (Fig. 5D), O. costulatus, O. florulentus, O. neurophyllus, O. occidentalis (Fig. 5E), O. phthirusoides, O. spicatus (Fig. 5C).

\section{ORYCTINA - Fig. 5F}

Fibers - Numerous fiber bundles throughout the lamina in O. atrolineata, most of them unbranched; occasionally a larger one will be forked at one end or even stellate. Oryctina pedunculata lacks fiber bundles but has some fibers associated with larger veins.

Sclereids - Astrosclereids with short, unbranched, often rounded to truncate arms, present throughout the lamina, or mostly at the base.

Cristarque cells - The two species sampled appear to lack cristarque cells.

Terminal tracheids - Large or small, in small clusters up to 4 cells, mostly isodiametric, rounded.

Comments - No general conclusions can be drawn from the small sample of species. Oryctina atrolineata may be distinct in the presence of two types of sclereids, one branched and single, the other simple and clustered; however, the latter may be brachysclereids, instead. Oryctina pedunculata lacks both fiber bundles and cristarque cells.

Species studied:

Oryctina atrolineata (Fig. 5F), O. pedunculata.

PANAMANTHUS PANAMENSIS (not illustrated)

Fibers - Veins accompanied by long, thick-walled fibers of somewhat undulate contours and by short fibers along smaller veins, but fiber bundles lacking.

Sclereids - None observed.

Cristarque cells - Small clusters along intermediate veins.

Terminal tracheids - Large, isodiametric, rounded, with transitional elements.

Comments - Morphologically, Panamanthus is extremely different from Struthanthus, which it resembles in general habit, but in terms of leaf anatomy the difference is insignificant.

\section{PHTHIRUSA - Fig. 6A-E}

Fibers - Thick-walled fibers present in P. disjectifolia; perhaps some thin-walled ones near the midrib of $P$. podoptera, but none observed in other species.

Sclereids - Astrosclereids present only in P. disjectifolia, where provided with extremely short, blunt arms, and superficially resembling small, uniform clumps of cristarque cells, and mostly concentrated near the larger veins; in some cases, they are 


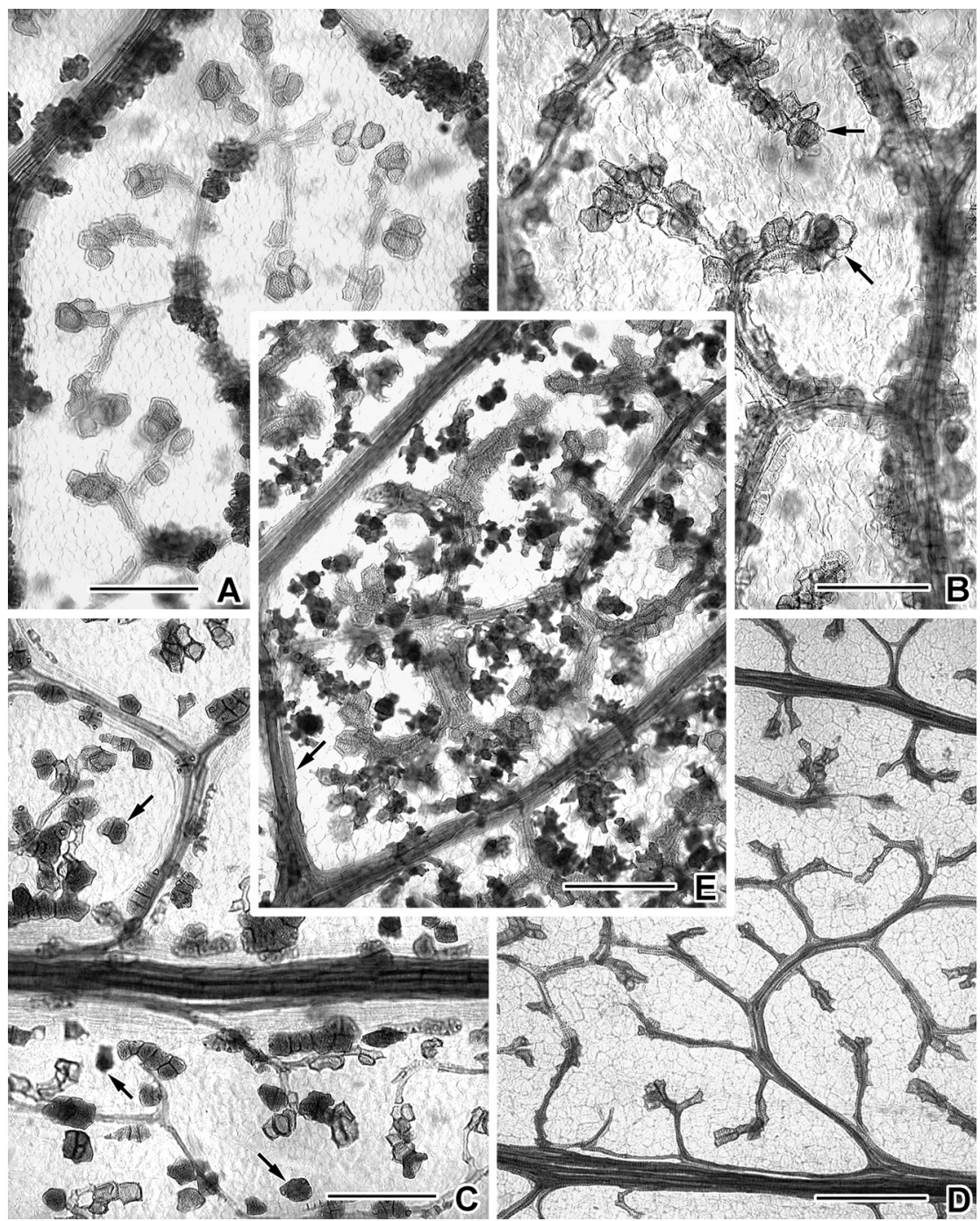

Fig. 6. Phthirusa. - A. Phthirusa pyrifolia: irregular, dense clumps of cristarque cells along intermediate veins (Kuijt 2425); B. Phthirusa lepidobotrys: nearly continuous clustering of cristarque cells along minor venation, mixed cristarque cells (arrows) and terminal tracheids (Harris \& Harris C.15109); C. Phthirusa stelis: short series of cristarque cells along midrib and intermediate veins; brachysclereids in mesophyll (arrows) (Woodson \& Schery 500); D. Phthirusa trichodes: absence of sclerenchyma, and weakly differentiated terminal tracheids (Van der Werff \& Ortíz 5419); E. Phthirusa disjectifolia: profuse astrosclereids, isolated short fibers (arrow), and absence of cristarque cells (Silva 2014). - Scale bar $=250 \mu \mathrm{m}$.

sufficiently abundant to nearly obscure the veins. Clusters of brachysclereids occur in $P$. stelis. Phthirusa podoptera shows small clumps of cells along major veins resembling cristarque cells in shape, but apparently lacking crystals. Phthirusa trichodes lacks any sort of sclerenchyma. 
Cristarque cells - Present and obvious in all species except $P$. disjectifolia and P. stenophylla, where they appear to be absent; in linear files and/or in clumps. In some species, only a few clumps are present near the base of the midrib (P. stelis) and are sufficiently abundant to nearly obscure the venation. In $P$. pyrifolia, there are large, irregularly shaped masses of cristarque cells spaced along subterminal portions of the venation, their concentration increasing with the thickness of the veins. Cristarque cell clusters are very small in P. podoptera. In P. stelis, some collections seem to lack cristarque cells (Killeen 7321) or nearly so (Woodson \& Schery 500).

Terminal tracheids - Present in small groups, mostly isodiametric, with transitional elements below which, especially in P. podoptera, completely encase the nearby veinlets, giving the impression of extraxylary fibers.

Comments - The genus Phthirusa at present consists of a very heterogeneous assemblage, its divergence being visible especially in its inflorescence and anther structure (unpubl. inf.). There appears to be a cluster of related species consisting of at least $P$. podoptera, $P$. pyrifolia, $P$. rufa, $P$. stelis and perhaps others which possess anthers nearly identical to the fertile ones of Dendropemon (see the illustration of P. podoptera and P. stelis in Kuijt, 1986, fig. 20, 22; Kuijt \& Kellogg, 1996, fig. 11). These Phthirusa species develop the same densely clustered cristarque cells which characterize Dendropemon. However, this anatomical feature shows considerable variation: it is poorly developed in P. podoptera where the clusters are very small. Some apparent variation in cristarque cell occurrence in $P$. stelis has been noted elsewhere.

Separate mention should be made of $P$. disjectifolia. Not only are cristarque cells lacking but a very distinctive type of individually distributed astrosclereids is abundant which bear short, blunt to lobed or truncate arms. Additionally, the large intermediate veins are reinforced by thick-walled fibers. These three anatomical features have not been observed in other Phthirusa species and suggest that the recent placement in Phthirusa may have to be reviewed.

The curious (and possibly misplaced) species $P$. trichodes exhibited neither sclereids nor cristarque cells.

Phthirusa stenophylla is distinctive in its very delicate reticulum, apparent lack of any sclerenchyma, and conspicuously scalariform-pitted terminal tracheids. The mixture of cristarque cells with terminal tracheids in P. lepidobotrys is noteworthy, and is also seen in Struthanthus and several species of Dendropemon.

Species studied:

Phthirusa disjectifolia (Fig. 6E), P. lepidobotrys (Fig. 6B), P. podoptera, P. pyrifolia (Fig. 6A), P. stelis (Fig. 6C), P. stenophylla, P. trichodes (Fig. 6D).

\section{PSITTACANTHUS - Fig. 7A-E}

Fibers - Generally absent and never in bundles; where occurring, they are short and infrequent, placed along intermediate veins ( $P$. oblongifolius, $P$. ramiflorus, and, very infrequently, $P$. martinicensis).

Sclereids - Psittacanthus demonstrates great variability in the occurrence, shape, and size of sclereids. Psittacanthus palmeri lacks sclereids completely, and few are present in $P$. angustifolius, $P$. calyculatus, $P$. cucullaris, $P$. gigas, $P$. linearis, $P$. schiedeanus, and P. sonorae; those on P. cucullaris and P. mayanus are found in the basal 
region of the lamina only. In $P$. linearis, sclereids are transitional in shape between astrosclereids and brachysclereids. In contrast, the leaves of P. barlowii, P. costaricensis, $P$. oblongifolius, $P$. ramiflorus, and $P$. wiensii have very high concentrations of astrosclereids. In P. oblongifolius the density of sclereids is such that the actual venation

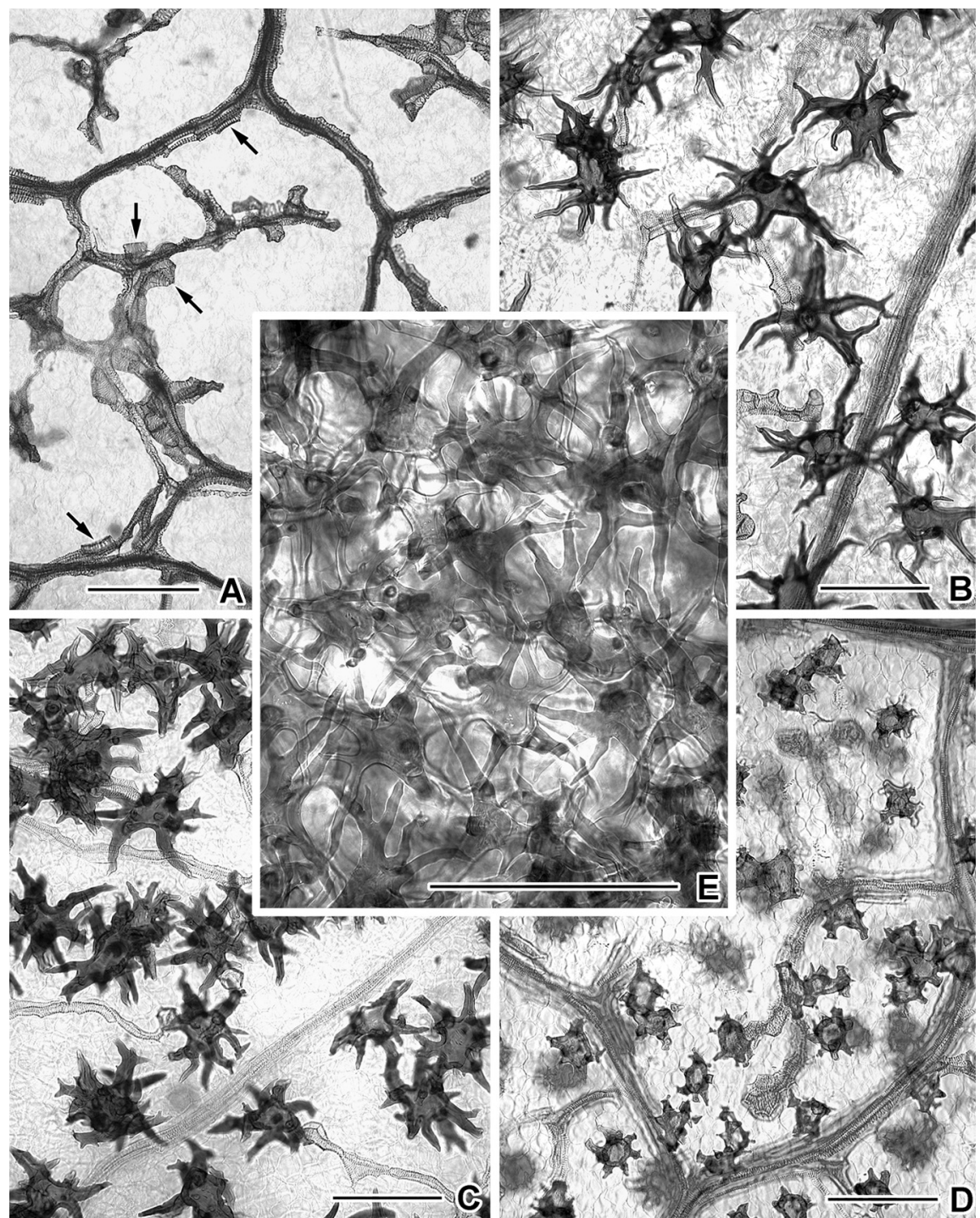

Fig. 7. Psittacanthus. - A. Psittacanthus palmeri: absence of sclerenchyma; slender terminal tracheids; transitional elements far down on veinlets (arrows) (Moore 5230); B. Psittacanthus barlowii: astrosclereids; absence of other sclerenchyma (David \& Yost 999); C. Psittacanthus wiensii: astrosclereids; absence of other sclerenchyma (Brandbyge \& Azanza 31928); D. Psittacanthus ramiflorus: short-armed astrosclereids; absence of other sclerenchyma (Kuijt 2488); E. Psittacanthus oblongifolius: dense astrosclereids obscuring venation (Klug 2254). - Scale bar $=250 \mu \mathrm{m}$. 
is entirely obscured. Sclereids may be very small - nearly of the brachysclereid type, as in P. angustifolius and $P$. cucullaris - or they may be very large astrosclereids with long, often sharply pointed arms, as in $P$. barlowii, $P$. oblongifolius, and $P$. wiensii. In size, also, Psittacanthus astrosclereids have a great range, from $35 \mu \mathrm{m}$ to $350 \mu \mathrm{m}$ in diameter, the former in P. angustifolius, the latter in P. barlowii.

Cristarque cells - Apparently absent in the genus.

Terminal tracheids - Present and prominent in all but one named species studied, their size and shape varying widely, often with transitional elements encasing the veinlets just behind the tips. In P. gigas, veinlets end with tracheary elements indistinguishable from those found elsewhere in the leaf. Psittacanthus calyculatus appears to have occasional single 'terminal' tracheids isolated in the parenchyma.

Comments - Van Tieghem, when creating his numerous segregate genera in Psittacanthus (Van Tieghem, 1895), seems to have paid particular attention to the occurrence of foliar sclerenchyma. Correcting for present-day synonymy, his main data may be summarized as follows:

1) Sclereids absent $-P$. americanus, $P$. auriculatus, $P$. calyculatus, $P$. clusiifolius, P. cordatus, $P$. cucullaris, $P$. divaricatus, $P$. schiedeanus.

2) Sclereids short-armed, including brachysclereids $-P$. biternatus, $P$. brachynema, P. glaucocoma, $P$. grandifolius, $P$. peronopetalus.

3) Sclereids long-armed $-P$. acinarius, $P$. americanus, $P$. crassifolius, $P$. decipiens, P. dichroos, $P$. drepanophyllus, $P$. eucalyptifolius, $P$. lamprophyllus, $P$. martinicensis, P. melinonii, P. pinguis, $P$. plagiophyllus, $P$. robustus, $P$. siphon, $P$. warmingii (= P. acinarius?).

Each of the above three groups contains species that taxonomically are not closely related. As examples of unrelated species may be mentioned: Group 1 ( $P$. cordatus$P$. schiedeanus), Group 2 (P. biternatus $-P$. peronopetalus), Group 3 ( $P$. acinariusP. siphon). Some inconsistencies in Van Tieghem's reporting may be due to different views of a taxonomic nature. The occurrence of $P$. americanus in both groups 1 and 3 may be such an instance. It is good to remember that the concept ' $P$. calyculatus' has been much confused in the past (Kuijt, 1987), often involving the erroneous reporting of P. americanus on the Mesoamerican continent. No voucher specimens were usually cited by Van Tieghem. The new genera segregated by this author from Psittacanthus have not been accepted by any subsequent worker. Neither Van Tieghem's new genera, nor the above grouping, appear to be correlated with the occurrence of foliar sclerenchyma.

Our own observations do not always agree with those of Van Tieghem. In contrast to his statements, we find some sclereids in P. calyculatus, $P$. cucullaris, and $P$. schiedea$n u s$. As mentioned earlier, there is a general tendency for sclereids to occur in greater concentrations in the basal portions of the blade, or perhaps be limited to the petiole, and it may be that Van Tieghem studied only more distant portions, where sclereids are indeed absent in some species. It is curious that Van Tieghem does not refer to foliar sclerenchyma in his numerous other papers on Loranthaceae; it is only in Psittacanthus that he provided such information.

No other neotropical genus of Loranthaceae has attained a comparable level of sclereid diversity. The complete lack of sclereids in the delicate, thin leaves of P. palmeri may be related to its presumed seasonal deciduousness under extreme, xeric conditions, 
It is interesting, in this context, that the deciduous Chilean Desmaria mutabilis equally lacks any type of sclerenchyma. However, there is no obvious correlation between foliar sclerenchyma and ecological factors in other species of Psittacanthus.

Both cristarque cells and (in most species) fibers seem to be essentially absent from Psittacanthus; terminal tracheids are present in all but one species studied, their size and form varying widely, often with transitional elements just behind the vein endings. Curiously, P. calyculatus occasionally has single cells of the same structure as terminal tracheids placed freely in the mesophyll. Psittacanthus gigas is unique in the genus in lacking terminal tracheids completely, the distal elements of veinlets being identical to those elsewhere.

Species studied:

Psittacanthus aff. amazonicus, P. angustifolius, P. barlowii (Fig. 7B), P. calyculatus, P. chiriquianus, $P$. costaricensis, $P$. cucullaris, $P$. dilatatus, $P$. gigas, $P$. linearis, $P$. martinicensis, . oblongifolius (Fig. 7E), P. palmeri (Fig. 7A), P. peculiaris, P. pusillus, P. ramiflorus (Fig. 7D), P. rhynchanthus, P. schiedeanus, $P$. sonorae, $P$. wiensii (Fig. 7C).

\section{STRUTHANTHUS - Fig. 8A-E}

Fibers - Extraxylary fibers are present in many species studied, but by no means uniformly so. They seem to be absent or nearly so in S. cansjeraefolius, $S$. cassythoides, S. costaricensis, S. quercicola, and S. salicifolius, and probably in S. uruguensis. In some species, an occasional, isolated fiber is present along intermediate veins, as in $S$. hartwegii and $S$. orbicularis. In $S$. matudai, only the midrib has a few long fibers. In S. leptostachyus, some of the junctions of the intermediate reticulum are reinforced with a few fibers which bend around the junctions. Along the midrib of the latter species, sclerified cells are occasionally present which are intermediate in shape between sclereids and fibers. Struthanthus polystachyus and S. woodsonii develop an even layer of long fibers along the intermediate and larger veins, and these are encrusted with small cristarque cells.

Sclereids - At least two species have well-developed astrosclereids (S. hartwegii and S. leptostachyus), but most species are without.

Cristarque cells - Present in all species studied (absent or inconspicuous in S. condensatus), isodiametric, and found in irregular clumps primarily near the base of the midrib, and encrusting the extraxylary fibers encasing extensive lengths of the larger veins; mixed with terminal tracheids in S. matudai.

Terminal tracheids - Present in all specimens studied, including transitional cells in subterminal positions, and generally angular and isodiametric in shape; the terminal tracheids of $S$. condensatus, however, are distinctively globular-rounded in shape.

Comments - Like Psittacanthus, Struthanthus exhibits a significant amount of variation in its foliar sclerenchyma. Terminal tracheids are present in all specimens examined, including transitional elements in subterminal positions. They are generally angular and more or less isodiametric in shape (slightly globular in S. condensatus). Cristarque cells, also, are present throughout except perhaps in S. condensatus, where they have not been identified. We cannot be certain about the presence of extraxylary fibers, as profuse cristarque cell differentiation often masks the intermediate veins. Such fibers may well accompany veins in S. leptostachyus (Fig. 8E) and S. uruguensis (Fig. 
8D). Struthanthus cassythoides, a species with often erect, small leaves, at first sight appears to develop fiber bundles similar to those of Oryctanthus, but the impression may simply be due to a sheath of differentiated cristarque cells. These cristarque cell 'sheaths' are mostly continuous with each other, extending along much of the intercon-

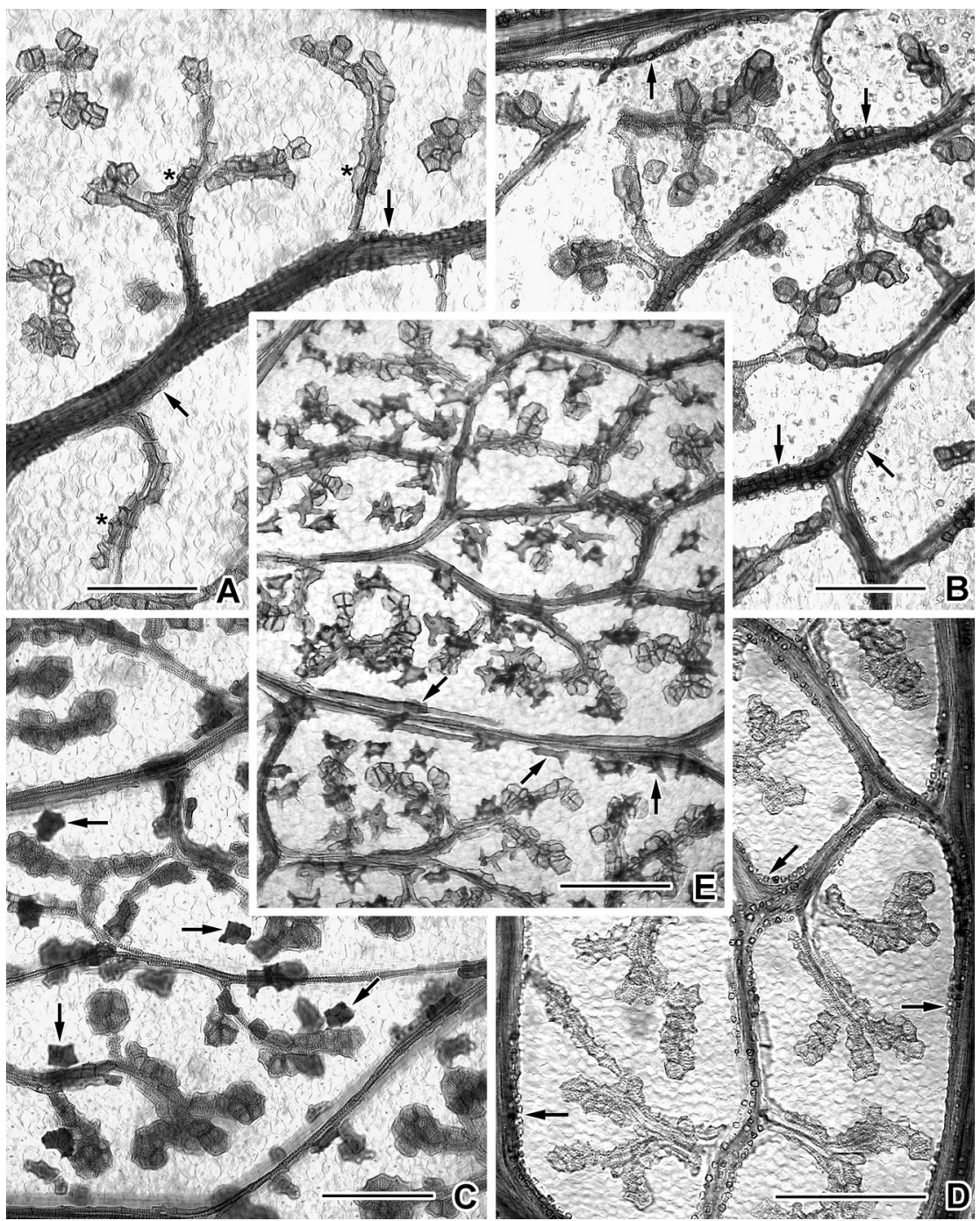

Fig. 8. Struthanthus. - A. Struthanthus costaricensis: continuous sheath of cristarque cells along intermediate veins (arrows); conspicuous transitional elements (*) (Kuijt 2439); B. Struthanthus cassythoides: continuous sheaths or series of cristarque cells along intermediate veins (arrows) and terminal tracheids (Steere 1369); C. Struthanthus hartwegii: brachysclereids (arrows); few, small clusters of cristarque cells (Matuda 3731); D. Struthanthus uruguensis: fairly small terminal tracheids; continuous cristarque cells along intermediate and larger veins (arrows) (Herter 1081); E. Struthanthus leptostachyus: profuse astrosclereids; individual, short fibers along veins, sometimes intermediate to sclereids (arrow) (Dodson \& Thien 1852). - Scale bar $=250 \mu \mathrm{m}$. 
nected part of its laminar venation. This is in contrast to Oryctanthus, where there are separate stellate units made up of simple fibers. Several other species of Struthanthus approach this condition, e.g., S. costaricensis, S. polystachyus, and S. quercicola. Several species have also developed astrosclereids, but most species are without. In $S$. condensatus, the mesophyll contains scattered astrosclereids of a very unusual type: they are characterized by both long and short, often branching and undulating arms, and are sometimes simple, fiber-like or nearly so. Occasionally such a nearly or quite unbranched cell is placed close to and parallel to a vein, and thus should perhaps be called a fiber. The secondary walls of these astroscleids are very thick and scarcely leave room for a lumen.

The presence of astrosclereids in the leaf of S. leptostachyus has been thought to give support to the intergeneric connection to Cladocolea, particularly $C$. primaria and $C$. archeri (Kuijt, 1981). The presence of chartaceous inflorescence bracts as well as certain aspects of inflorescence morphology were the main morphological features suggesting this transgeneric connection. Similar chartaceous bracts are present in at least one additional Struthanthus, S. polystachyus, but that species seems to lack sclereids in the lamina. The suggested evolutionary connection between $C$. primaria and S. leptostachyus and others would be an interesting subject for future studies, and should include other species characterized by chartaceous bracts such as $C$. roraimensis and S. polystachyus.

Foliar sclereids are not limited to the above species, however, and are present in $S$. hartwegii as dispersed brachysclereids with obtuse angles and extremely heavy secondary walls. That species surely bears no direct relationship to the above-mentioned species of Struthanthus and Cladocolea.

The occurrence of astrosclereids in S. leptostachyus and S. condensatus demonstrates how careful we must be in drawing taxonomic conclusions on such features. Reference to the full morphology of these two species immediately shows that they are not directly related, and that their astrosclereids thus must have evolved separately. It is not surprising that the sclereids in these two species are very different structurally.

In at least $S$. cansjeraefolius and $S$. cassythoides, long sleeves of cristarque cells on intermediate veins may give the impression of stellate fiber bundles, but fibers appear to be absent (Fig. 8B). The same is true for some specimens of S. uruguensis (Herter 1081), while another collection was found to have virtually no cristarque cells (Lindman 1003). More or less continuous series of cristarque cells characterize $S$. quercicola.

Species studied:

Struthanthus cansjeraefolius, S. cassythoides (Fig. 8B), S. condensatus, S. costaricensis (Fig. 8A), S. hartwegii (Fig. 8C), S. leptostachyus (Fig. 8E), S. matudai, S. oerstedii, S. polystachyus, S. quercicola, S. salicifolius, S. uruguensis (Fig. 8D), S. woodsonii.

\section{TRIPODANTHUS - Fig. 9A, B}

Fibers - Extraxylary fibers associated with all but the smallest veins, and encrusted with a layer of small, uniform cristarque cells. In T. flagellaris, the fiber bundles are made up of short, blunt fibers.

Sclereids - Not observed. 
Cristarque cells - Ensheathing fiber bundles in T. acutifolius but absent in T. flagellaris.

Terminal tracheids - Present in small groups, moderately large, with transitional tracheids below.
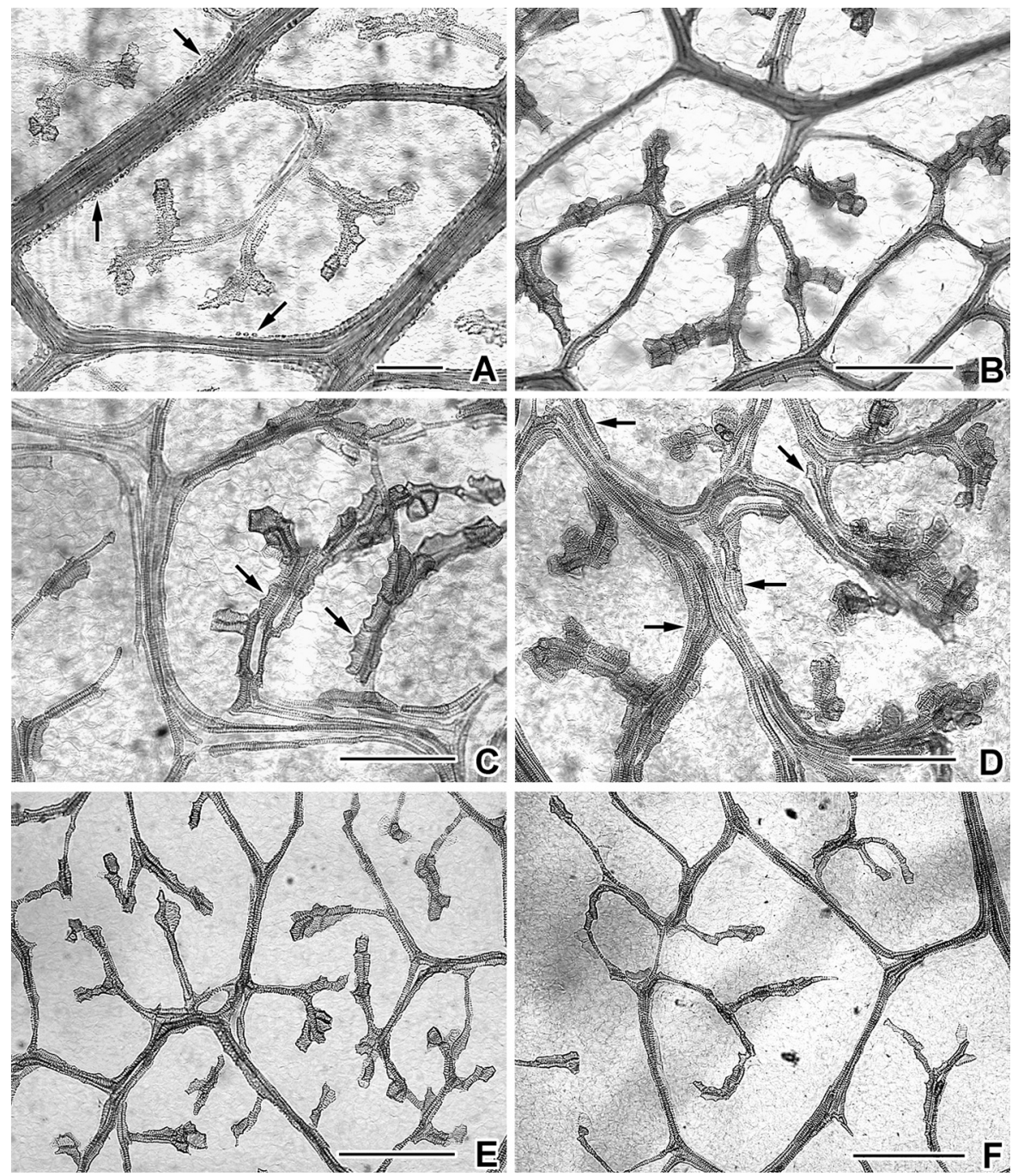

Fig. 9. Tripodanthus, Tristerix, Loranthus europaeus, and Tupeia antarctica. - A. Tripodanthus acutifolius: long series of cristarque cells along intermediate veins (arrows); weakly differentiated terminal tracheids (Da Costa Sacco 977); B. Tripodanthus flagellaris: absence of all sclerenchyma (Herter 1701); C. Tristerix longebracteatus: absence of all sclerenchyma; weakly differentiated terminal tracheids; well-developed transitional elements (arrows) (Cuatrecasas 14661); D. Tristerix chodatianus: profuse, elongated transitional elements (arrows) (Weberbauer 5434); E. Loranthus europaeus: absence of sclereids; weakly differentiated transitional elements (collected near Vienna, 1959); F. Tupeia antarctica: absence of sclereids; weakly differentiated terminal tracheids (Kirk s.n.).

- Scale bar $=250 \mu \mathrm{m}$. 
Comments - The foliar sclerenchyma of Tripodanthus shows no particularly distinctive features.

Extraxylary fibers uniformly encase all but the smallest veins in T. acutifolius, and are encrusted with a layer of small cristarque cells. In T. flagellaris there appears to be no sclerenchyma of any sort, and no cristarque cells have been observed. Terminal tracheids are rather small in both species, and in T. acutifolius tend to be spread along the distal portions of veinlets.

Species studied:

Tripodanthus acutifolius (Fig. 9A), T. flagellaris (Fig. 9B).

\section{TRISTERIX - Fig. 9C, D}

Fibers - A short occasional one in T. corymbosus and maybe other species. In T. chodatianus and T. peruvianus, there are some long, slender, undulating fibers here and there which run parallel and near to the intermediate veins, or an occasional short, blunt fiber near the largest vascular bundles (T. corymbosus).

Sclereids - A few small brachysclereids were observed near the lower midrib of $T$. chodatianus, but not in other species.

Cristarque cells - There appear to be none in any species.

Terminal tracheids - Present in all species studied, angular and isodiametric (weakly differentiated in T. corymbosus and T. verticillatus); transitional elements present, perhaps encasing much of the smaller venation.

Comments - The Tristerix species studied are characterized by a paucity of sclerenchyma of any sort except for the few basal sclereids of T. chodatianus and an infrequent fiber in T. corymbosus and T. peruvianus. The almost total absence of cristarque cells is a distinctive feature.

Species studied:

Tristerix chodatianus (Fig. 9D), T. corymbosus, T. longebracteatus (Fig. 9C), T. penduliflorus, T. peruvianus, T. verticillatus.

\section{DISCUSSION}

Although foliar sclerenchyma has been described for numerous angiosperms (see the survey by Rao, 1991), its use as taxonomic information has been very limited. Within Loranthaceae, foliar sclerenchyma has been reported only incidentally, and only in very few genera. The most striking example is in Oryctanthus (Kuijt, 1961) where structural features were demonstrated that were considered to be of diagnostic generic value. In the case of Cladocolea archeri and Struthanthus leptostachyus, the presence of foliar sclereids has been used to underline their mutual affinity visible also from other structural features (Kuijt, 1981: 10). Interestingly, a great deal of sclerenchyma information is available for other families of Santalales, where its diversity may rival that in Loranthaceae (Rao, 1991: 143-160.). This is of particular interest since Loranthaceae are presumed to have arisen from Olacaceae (Kuijt, 1968) a view which has more recently been corroborated by rRNA sequence analysis (Nickrent \& Franchina, 1990).

The dominant impression which emerges from our data is of the great divergence that has evolved in the leaf architecture of neotropical Loranthaceae. Especially when 
considering the numerous unexplored palaeotropical genera, the family may well show more variation in this regard than other angiosperm families. The great spectrum of leaf anatomy in neotropical genera is an interesting parallel to that of anther morphology (pers. inf.), pollen (Feuer \& Kuijt, 1979a, b, 1985), inflorescence architecture (Kuijt, 1981), seedling morphology (Kuijt, 1982), and karyology (Barlow \& Wiens, 1971). It includes at least one sclerenchyma type apparently unique in angiosperms (Notanthera).

While certain anatomical features show a high degree of taxonomic constancy in our survey (e.g., the absence of fibers in Dendropemon and Tristerix, of cristarque cells in Psittacanthus, and of sclereids in Tristerix and many species of Struthanthus), in other cases there is much intrageneric variation, summarized below. Significant anatomical variation may sometimes exists within a species, as especially in Gaiadendron punctatum (see below).

\section{FIBERS}

Our information on fibers is very incomplete except in a couple of instances. This incompleteness is largely due to the difficulty of identifying fibers when closely associated with larger veins, which is their usual position in the leaf. In addition to the unique serpentine fibers as detailed below for Notanthera, only stellate fiber bundles require discussion.

As stated above, the striking stellate fiber bundles represent a clustering of simple extraxylary fibers which, in the aggregate, are mostly branched and associated with sharply delimited, subterminal portions of the vascular skeleton. These compound bundles were first described and illustrated for Oryctanthus (Kuijt, 1961) and were originally thought to be diagnostic for Oryctanthus. Our present results, however, show this to have been a misconception. While it is true that all known species of Oryctanthus possess them, similar bundles are also present in several species not belonging to that genus. The most striking example is in Oryctina atrolineata (Fig. $5 \mathrm{~F}$ ). As mentioned above, this is not a matter of taxonomic misplacement, as may be seen in their inflorescence structure and floral details (Kuijt, 2003). Struthanthus cassythoides is a species with small, generally erect leaves. Much of the interconnected part of its laminar venation is associated with fiber bundles very much like those of Oryctanthus. However, the fiber bundles in this case are mostly continuous with each other, not forming separate stellate units as in Oryctanthus and Oryctina. Similarly, S. costaricensis (Fig. 8A) and S. quercicola show rather slender, poorly defined fiber bundles, and several other species of Struthanthus have at least occasional fibers flanking the vascular system. In S. leptostachyus, curved fibers reinforce many of the vein junctions of the minor reticulum, again forming an approximation of stellate bundles. Gaiadendron shows considerable variation in this regard: in one collection (Dodson \& Thien 1521) slender fiber bundles were seen, while in other collections they were not in evidence. Since the above examples of stellate fiber bundles are drawn from at least three separate taxonomic locations we may conclude that their evolution has occurred several times. 
Table 1 . General summary of foliar sclerenchyma and related features by genus.

\begin{tabular}{|c|c|c|c|c|c|}
\hline Genus & $\begin{array}{l}\text { Astro } \\
\text { sclereids }\end{array}$ & $\begin{array}{l}\text { Cristarque } \\
\text { cells }\end{array}$ & $\begin{array}{l}\text { Brachy- } \\
\text { sclereids }\end{array}$ & $\begin{array}{l}\text { Terminal } \\
\text { tracheids }\end{array}$ & Fibers \\
\hline Aetanthus & $+/-$ & - & - & + & $(-)$ \\
\hline Cladocolea & $+1-$ & $(+) /-$ & - & + & $-/(+)$ \\
\hline Dendropemon & - & + & - & + & - \\
\hline Desmaria & - & - & - & + & - \\
\hline Gaiadendron & - & $+/(-)$ & - & + & $(+)$ \\
\hline Ixocactus & - & + & $-/(+)$ & + & - \\
\hline Ligaria & + & - & - & - & - \\
\hline Notanthera & - & - & - & - & serp. fibers \\
\hline Oryctanthus & $+1-$ & + & $+1-$ & + & + \\
\hline Oryctina & + & - & - & + & $+/-$ \\
\hline Panamanthus & - & + & - & + & - \\
\hline Phthirusa & $-/(+)$ & $+/(-)$ & - & + & $-/(+)$ \\
\hline Psittacanthus & $+/(-)$ & $-/(+)$ & $(+)$ & $+/(-)$ & - \\
\hline Struthanthus & $-/(+)$ & $+/(-)$ & $-/(+)$ & + & $?$ \\
\hline Tripodanthus & - & $+1-$ & - & + & + \\
\hline Tristerix & - & - & $-/(+)$ & + & - \\
\hline
\end{tabular}

Symbols: + present; (+) rarely present; - absent; (-) rarely absent; +/- present in some, absent in others

\section{SCLEREIDS}

It is clear from the above presentation and Table 1 that foliar sclereids are frequently developed in the leaves of neotropical Loranthaceae. Their complete absence from the entire leaf of others cannot be proven without detailed anatomical work on petioles, which is beyond the scope of our work. In the small-leaved Phthirusa trichodes only it was possible to treat entire leaves, which lack sclereids completely. A gradient of frequency is sometimes evident from leaf margins to the base of the blade (e.g., Psittacanthus cucullaris; some of this can be seen in Dendropemon, Fig. 3C, D), and the extreme condition of this is the total absence of sclereids from the main part of the blade and presence of at least some sclereids in or near the petiole (e.g., Psittacanthus schiedeanus, Tristerix chodatianus, and especially Oryctina atrolineata). This factor may account for some discrepancies between Van Tieghem's and our observations, as mentioned above for Psittacanthus.

\section{CRISTARQUE CELLS}

Cristarque cells are poorly known cell types in vascular plants, as also indicated by their complete absence from two major texts in plant anatomy (Esau,1953, Fahn, 1967) and even from the compendium of foliar sclereids by Rao (1991). They tend to be highly diagnostic taxonomically, because they occur in only a few families (Dickison, 2000). Our survey shows cristarque cells to be present in many genera, but they have not been detected in some taxa, as in Ligaria and Notanthera. Some species of Aetanthus lack them while they were seen in other species. They are extremely common and obvious in Phthirusa but appear to be absent in P. disjectifolia and P. stenophylla. The close 
affinity of (at least some species of) Phthirusa with Dendropemon is underlined by the presence and abundance of cristarque cells in every species studied in the latter genus. Psittacanthus seems to lack cristarque cells throughout. Curiously, some plants of Gaiadendron punctatum lack this cell type or nearly so (Fig. 4A, B) while others have them in abundance (Fig. 1C).

Cristarque cells are commonly present in simple or compound linear series associated with relatively small to large veins, but often form characteristic, separate clusters along the reticulum throughout Dendropemon and in most species of Phthirusa. In $D$. constantiae the larger veins are nearly obscured by dense clusters of cristarque cells. In two other species of Dendropemon, D. pauciflorus and D. pycnophyllus, and in Struthanthus matudai, cristarque cells and terminal tracheids are intermixed at the tips of veinlets but also in groups along more proximate vein portions. It is common for cristarque cells to be associated with the external surface of fiber bundles, as exemplified especially in Oryctanthus; however, they may also be associated with vein portions which lack fibers, as in most species of Struthanthus studied. Baas et al. (1982) report that cristarque cells are very common in Olacaceae, and suggest that "their occurrence might be considered an ancestral condition in the Olacaceae". Our data are compatible with that concept. As mentioned earlier, Olacaceae are regarded as basal in Order Santalales (Nickrent \& Franchina, 1990).

In some cases, the crystals near fibers are so small that they appear to adhere to the outside of those cells (e.g. Gaiadendron), but the crystals in question probably are enclosed in a very small type of cristarque cells. Crystals are normally formed in vacuoles or are possibly embedded in the cell wall (Esau, 1953: 29). In one instance, we have observed a case where most cristarque cells are free in the mesophyll.

Struthanthus cansjeraefolius is unusual in that slender series of cristarque cells occur on intermediate veins but not on major veins or on the midrib. This is the reverse of the common rule; more commonly, the concentration of cristarque cells increases towards the base of the leaf, as in many species of Dendropemon. This pattern is parallel to the gradient in distribution often seen in sclereids (see below). In Struthanthus matudai (Fig. 1D) and a few others a special form of cristarque cell is present in which the enclosed crystal is not cuboidal but rounded on the outer surface. This type of crystalliferous cell does not seem to have been reported in the anatomical literature. Another peculiarity is that in some species like Dendropemon pauciflorus and D. pycnophyllus, cristarque cells occur not only along the veins but also interspersed among terminal tracheids.

Noteworthy is the variation of cristarque cells in Oryctanthus, as detailed above for that genus, including the intermediate forms to sclereids in one of its species.

\section{TERMINAL TRACHEIDS}

Terminal tracheids do not appear to be very common in other dicotyledons but are frequent in other families of Santalales (Rao, 1991). They are mentioned as characteristic of Loranthaceae even in Solereder (1899). They are present in nearly all genera of our survey, even though they vary in the degree of differentiation. In some species (e.g., Dendropemon sessiliflorus) they nearly fill the areoles, while in others the individual terminal tracheids are only slightly larger than adjacent tracheary elements, 
even though they mostly differ somewhat in shape (Fig. 2A, 3E, 4C, 6D, 9E, F). We have not detected them in Notanthera nor in Psittacanthus gigas.

As mentioned in our introduction, the functional status of terminal tracheids is an open question. The most essential fact which remains to be established in this context is whether they contain living protoplasts at maturity, and what their ultrastructural features are if they do. The leaves of most tropical Loranthaceae would clearly provide excellent material for such a study.

\section{ACKNOWLEDGEMENTS}

The support of the Natural Sciences and Engineering Research Council of Canada is gratefully acknowledged. We are most obliged to Dr. Louise Page for the use of optical equipment.

\section{REFERENCES}

Baas, P. \& R. Kool. 1983. Comparative leaf anatomy of Heisteria (Olacaceae). Blumea 28: 367388.

Baas, P., E. van Oosterhoud \& C.J.L. Scholtes. 1982. Leaf anatomy and classification of the Olacaceae, Octoknema, and Erythropalum. Allertonia 3: 155-209.

Barlow, B.A. \& D. Wiens. 1971. The cytogeography of the Loranthaceous mistletoes. Taxon 20: 291-312.

Berlyn, G.P. \& J.P. Miksche. 1976. Botanical microtechnique and cytochemistry. Iowa State Univ. Press, Ames, Iowa.

Danser, B.H. 1933. A new system for the genera of Loranthaceae Loranthoideae, with a nomenclator for the Old World species of this subfamily. Verh. Kon. Ned. Akad. Wetensch., Afd. Natuurk., Tweede Sect. 29: 1-128.

Dickison, W.C. 2000. Integrative plant anatomy. Academic Press, New York.

Eichler, A.W. 1868. Loranthaceae. In: K. Martius, Fl. Brasiliensis 5, 2: 1-136.

Engler, A. \& K. Krause. 1935. Loranthaceae. In: A. Engler, Die natürlichen Pflanzenfamilien 16b: 98-203.

Esau, K. 1953. Plant anatomy, 2nd ed. Wiley \& Sons, New York.

Esau, K. 1977. Anatomy of seed plants, 2nd ed. Wiley \& Sons, New York.

Fahn, A. 1967. Plant anatomy. Pergamon Press, Oxford.

Fernández, T.B., B.G. Varela, A. Taira, R.A. Ricco, A.G. Gurni, S.E. Hajos, E.M.C. Alvárez \& M.L. Wagner. 2000. Ligaria cuneifolia var. cuneifolia as a substitute for the European mistletoe (Viscum album L.). In: A. Büssing (ed.), Mistletoe. The genus Viscum. Harwood Acad. Publ.

Feuer, S. \& J. Kuijt. 1979a. Fine structure of mistletoe pollen. II. Pollen morphology and evolution in the genus Psittacanthus Mart. Bot. Not. 132: 295-309.

Feuer, S. \& J. Kuijt. 1979b. Fine structure of mistletoe pollen. III. Large-flowered neotropical Loranthaceae and their Australian relatives. Amer. J. Bot. 67: 34-50.

Feuer, S. \& J. Kuijt. 1985. Fine structure of mistletoe pollen. VI. Small-flowered neotropical Loranthaceae. Ann. Missouri Bot. Gard. 72: 187-212.

Foster, A.S. 1947. Structure and ontogeny of the terminal sclereids in the leaf of Mouriria huberi Cogn. Amer. J. Bot. 34: 501-514.

Foster, A.S. 1950. Practical plant anatomy. 2nd ed. Van Nostrand Co., New York.

Heinricher, E. 1885. Über einige im Laube dikotyler Pflanzen trockenen Standorts auftretende Einrichtungen, welche mutmässlich eine ausreichende Wasserversorgung des Blattmesophylls bezwecken. Bot. Zentralbl. 23: 25-56.

Kuijt, J. 1961. Notes on the anatomy of the genus Oryctanthus (Loranthaceae). Canad. J. Bot. 39: $1809-1816$.

Kuijt, J. 1963. On the ecology and parasitism of the Costa Rican tree mistletoe, Gaiadendron punctatum (Ruiz \& Pavon) G. Don. Canad. J. Bot. 41: 927-938. 
Kuijt, J. 1968. Mutual affinities of Santalalean families. Brittonia 20: 136-147.

Kuijt, J. 1975. The genus Cladocolea (Loranthaceae). J. Arnold Arbor. 56: 265-335.

Kuijt, J. 1976. Revision of the genus Oryctanthus (Loranthaceae). Bot. Jahrb. Syst. 95: 478-534.

Kuijt, J. 1981. Inflorescence morphology of Loranthaceae - an evolutionary synthesis. Blumea 27: $1-73$.

Kuijt, J. 1982. Seedling morphology and its systematic significance in Loranthaceae of the New World, with supplementary comments on Eremolepidaceae. Bot. Jahrb. Syst. 103: 305-342.

Kuijt, J. 1985. Morphology, biology, and systematic relationships of Desmaria (Loranthaceae). Pl. Syst. Evol. 151: 121-130.

Kuijt, J. 1986. Loranthaceae. In: G. Harling \& B. Sparre (eds.), Fl. Ecuador 32C: 115-197.

Kuijt, J. 1987. Novelties in Mesoamerican mistletoes (Loranthaceae and Viscaceae). Ann. Missouri Bot. Gard. 74: 511-532.

Kuijt, J. 1989. Additional notes on the parasitism of New World Loranthaceae. Beitr. Biol. Pflanzen 64: $115-125$.

Kuijt, J. 1992. Nomenclatural changes, new species, and a revised key for the genus Oryctanthus (Loranthaceae). Bot. Jahrb. Syst. 114: 173-183.

Kuijt, J. 2003. A new species of Oryctina (Loranthaceae) from Guyana. Brittonia 55: 169-172.

Kuijt, J. \& E. A. Kellogg. 1996. Miscellaneous mistletoe notes, 20-36. Novon 6: 33-53.

Lersten, N.R. 1967. An annotated bibliography of botanical clearing methods. Iowa State J. Sci. 41: 481-486.

Metcalfe, C.R. \& L. Chalk. 1950. Anatomy of the dicotyledons. Clarendon Press, Oxford.

Napp-Zinn, K. 1973. Anatomie des Blattes. II. Blattanatomie der Angiospermen. A. Entwicklungsgeschichtliche und topographische Anatomie des Angiospermen-blattes. In: G. Tischler \& A. Pascher (eds.), Handbuch der Pflanzenanatomie 8 (2A, 1).

Nickrent, D.L. \& C.R. Franchina. 1990. Phylogenetic relationships of the Santalales and relatives. J. Molec. Evol. 31: 294-301.

Pirwitz, K. 1931. Physiologische und anatomische Untersuchungen an Speichertracheiden und Velamina. Planta 14: 19-76.

Rao, A.R. \& M. Malaviya. 1962. The distribution, structure and ontogeny of sclereids in Dendrophthoe falcata (L.f.) Ettings. Proc. Indian Acad. Sci. 55: 239-243.

Rao, T.A. 1991. Compendium of foliar sclereids in Angiosperms: morphology and taxonomy. Wiley Eastern, New Delhi.

Rao, T.A. \& S. Das. 1979. Typology of foliar tracheoids in Angiosperms. Proc. Indian Acad. Sci., B, 88: 331-345.

Rao, T.A. \& S.S. Kelkar. 1951. Studies on foliar sclereids in dicotyledons. III. On sclereids in species of Loranthus (Loranthaceae) and Niebuhria apetala (Capparidaceae). J. Univ. Bombay 20: 18-20.

Rao. T.A. \& K.J. Mody. 1961. On terminal sclereids and tracheoid idioblasts. Proc. Indian Acad. Sci., B, 53: 257-262.

Reiche, K. 1907. Bau und Leben der hemiparasitischen Phrygilanthus-Arten Chiles. Flora 97: $375-400$.

Solereder, H. 1899. Systematische Anatomie der Dicotyledonen. Enke, Stuttgart.

Van Tieghem, P. 1895. Sur le groupement des espèces en genres dans la tribu des Psittacanthées de la famille des Loranthacées. Bull. Soc. Bot. France 42: 343-362.

Varela, B.G. \& A.A. Gurni. 1995. Anatomía foliar y caulinar comparativa del muérdago criollo y del muérdago europeo. Acta Farmacéutica Bonaerense 14: 21-29.

Varela, B.G. \& A. A. Gurni. 1998. Anatomía foliar y caulinar comparativa de la 'Liga' [Ligaria cuneifolia (R. et P.) Tiegh.] y la 'Liga Blanca' [Tripodanthus flagellaris (Cham. et Schlecht.) Tiegh.]. Acta Farmacéutica Bonaerense 17: 113-120.

Varela, B.G. \& A.A. Gurni. 1999. Estudios anatómicos comparativos de dos especies de Loranthaceae provenientes de Jujuy (Argentina). Acta Farmacéutica Bonaerense 18: 251-256. 
APPENDIX. List of voucher specimens of species studied.

Aetanthus aff. andreanus (Tiegh.) Engl. (Lewis \& Lozano 3646, LEA)

Aetanthus macranthus (Hook.) Kuijt (Palacios et al. 2548, LEA)

Aetanthus nodosus (Desr.) Engl. (Macbride 4900, LEA)

Cladocolea alternifolia (Eichler) Kuijt (Lombardi 4980, LEA)

Cladocolea archeri (A.C. Sm.) Kuijt (Fagerlind \& Wibom 1758, S)

Cladocolea coriacea Kuijt (Davidse \& González 14281, LEA)

Cladocolea cupulata Kuijt (Díaz Luna 5176, LEA)

Cladocolea loniceroides (Tiegh.) Kuijt (Iltis et al. 29503, LEA)

Cladocolea microphylla (Kunth) Kuijt (Pringle 4369, F)

Cladocolea nitida Kuijt (Henkel et al. 4400, LEA)

Cladocolea peruviana Kuijt (Díaz \& Fernández, 10152, LEA)

Cladocolea primaria Kuijt (D'Arcy \& Hamilton 14187, LEA)

Cladocolea pringlei (Pringle 5058, GH)

Cladocolea roraimensis (Steyerm.) Kuijt (Steyermark 58943, F)

Dendropemon alatus Tiegh. (Leonard \& Leonard 4070, GH)

Dendropemon bistriatus Urb. (Zanoni et al. 18525, LEA)

Dendropemon brachycarpus Urb. (Ekman H-2248, LEA)

Dendropemon caribaeus (Engl.) Krug \& Urb. (Ricksecker 313, UC)

Dendropemon constantiae Krug \& Urb. (Zanoni et al. 21804, LEA)

Dendropemon emarginatus (Sw.) Tiegh. (Eggers 375, GH; Sintenis 4401, UC)

Dendropemon parvifolius (Sw.) Steud. (Von Türckheim 3242, GH)

Dendropemon pauciflorus (Sw.) Tiegh. (Orcutt 2676, UC)

Dendropemon picardae Krug \& Urb. (Zanoni et al. 39919, LEA)

Dendropemon psilobotrys (DC.) Tiegh. (Ekman H-14297, LEA)

Dendropemon purpureus (L.) Krug \& Urb. (Howard et al. 302, UC)

Dendropemon pycnophyllus Krug \& Urb. (Howard \& Howard 9051, GH)

Dendropemon rostratus Urb. (Ekman H-10481, LEA)

Dendropemon sessiliflorus Urb. (Zanoni et al. 23200, LEA)

Dendropemon uniflorus (Jacq.) Steud. (Leonard \& Leonard 15026, UC)

Desmaria mutabilis (Poepp. \& Endl.) Tiegh. (Eyerdam 10192, UC; Sargent s.n., GH)

Gaiadendron punctatum (Ruiz \& Pav.) G. Don (Bang 1569, GH; 58-31, Dodson \& Thien 1332, QCA; Dodson \& Thien 1521, MO; Kuijt 1534, 2471, CR)

Ixocactus clandestinus (Mart.) Kuijt (Amorim et al. 1902, LEA)

Ixocactus gracilis Kuijt (Roldán et al. 1165, LEA)

Ixocactus inconspicuus (Benth.) Kuijt (Gentry 7056, F; Lott 2613, LEA)

Ixocactus inornus (B.L. Rob. \& Greenm.) Kuijt (Smith 122, GH; Smith et al. 4127, F)

Ixocactus rhynchophyllus Kuijt (Luteyn \& Atehortúa 11853a, LEA)

Ligaria cuneifolia (Ruiz \& Pav.) Tiegh. (Venturi 10297, GH; Stork \& Horton 9400, UC)

Loranthus europaeus L. (Vienna, collected Kuijt, 1959)

Notanthera heterophylla (Ruiz \& Pav.) G. Don (Bertero 1474, GH; Eyerdam 10608, F; Landrum 3850, LEA; Meyer 9757, LEA)

Oryctanthus alveolatus (Kunth) Kuijt (Kuijt 2567, CR)

Oryctanthus cordifolius (C. Presl) Urb. (Kuijt 2571, CR)

Oryctanthus costulatus Rizzini (Liesner \& González 13062, LEA)

Oryctanthus florulentus (Rich.) Urb. (Lanjouw \& Lindeman 1994, K)

Oryctanthus neurophyllus Kuijt (Gentry et al. 53663, LEA)

Oryctanthus occidentalis (L.) Eichler (Kuijt 2413, CR)

Oryctanthus phthirusoides Rizzini (Maguire et al. 36455, MO)

Oryctanthus spicatus (Jacq.) Eichler (Gentle 1426, NY; Kuijt 2441, CR, 2476, CR; )

Oryctina atrolineata Kuijt (Pipoly \& Godfrey 7388, LEA)

Oryctina pedunculata Kuijt (Dorr \& Barnett 7611, LEA) 
Panamanthus panamensis (Rizzini) Kuijt (McPherson 93870, LEA)

Phthirusa disjectifolia (Rizzini) Kuijt (Silva 2014, LEA)

Phthirusa lepidobotrys (Griseb.) Eichler (Harris \& Harris C.15109, UC)

Phthirusa podoptera (Cham. \& Schltdl.) Kuijt (Lombardi 361, LEA)

Phthirusa pyrifolia (Kunth) Eichler (Kuijt 2425, CR)

Phthirusa stelis (L.) Kuijt (Woodson \& Schery 500, GH; Killeen 7321, LEA)

Phthirusa stenophylla Eichler (Henkel et al. 762, LEA)

Phthirusa trichodes Rizzini (Van der Werff \& Ortíz 5419, LEA)

Psittacanthus aff. amazonicus (Ule) Kuijt (Daly et al. 5673, LEA))

Psittacanthus angustifolius Kuijt (Moreno 24419, LEA)

Psittacanthus barlowii Kuijt (Davis \& Yost 999, GH)

Psittacanthus calyculatus (DC.) G. Don (García M. 764, LEA; Kuijt 2496, CR)

Psittacanthus chiriquianus Kuijt (Almeda \& Nakai 3477, LEA)

Psittacanthus costaricensis Kuijt (Hammel et al. 16949, LEA)

Psittacanthus cucullaris (Lam.) Blume (Guillén \& Roca 3347, LEA)

Psittacanthus dilatatus A.C. Sm. (Roldán et al. 1159, LEA)

Psittacanthus gigas Kuijt (Gentry et al. 48280, LEA)

Psittacanthus linearis (Killip) J.F. Macbr. (= P. divaricatus) (Chrostowski 7-13, LEA)

Psittacanthus martinicensis (C. Presl in Schult. \& Schult.) Eichler (Pinchon 23, LEA)

Psittacanthus oblongifolius (Rusby) Kuijt (Klug 2254, GH)

Psittacanthus palmeri (Watson) Barlow \& Wiens (Moore 5230, GH)

Psittacanthus peculiaris A.C. Sm. (Gentry et al. 36505, LEA)

Psittacanthus pusillus Kuijt (Sytsma 1973, LEA)

Psittacanthus ramiflorus (DC.) G. Don (Kuijt 2479, 2488, CR)

Psittacanthus rhynchanthus (Benth.) Kuijt (Kuijt 2496)

Psittacanthus schiedeanus (Cham. \& Schltdl.) Blume (Calzada 2093, LEA; Kuijt 2462, CR)

Psittacanthus sonorae (Watson) Kuijt (Carter \& Kellogg 2946, GH)

Psittacanthus wiensii Kuijt (Brandbyge \& Azanza 31928, AAU; Oellgaard et al. 35116, AAU)

Struthanthus cansjeraefolius Oliv. (Oersted 3109, C; Kuijt 2461, CR)

Struthanthus cassythoides Standl. (Steere 1369, NY)

Struthanthus condensatus Kuijt (Lott \& Upson 3908, LEA)

Struthanthus costaricensis Standl. (Kuijt 2439, CR)

Struthanthus hartwegii (Benth.) Standl. (Matuda 3731, MICH)

Struthanthus leptostachyus (Kunth) G. Don (Kuijt 2445, 2449, 2505, 2558, CR; Dodson \& Thien 1852, LEA)

Struthanthus matudai Lundell (Matuda 1808, MICH)

Struthanthus oerstedii (Oliv.) Standl. \& Calderón (Kuijt 2457, CR)

Struthanthus polystachyus (Ruiz \& Pav.) G. Don (Gentry \& Young 31709, LEA)

Struthanthus quercicola (Cham. \& Schltdl.) Blume (Kuijt 2554, CR)

Struthanthus salicifolius Mart. (Pereira 5669, F)

Struthanthus uruguensis (Hook. \& Arn.) G. Don (Lindman 1003, GH; Herter 1081, F)

Struthanthus woodsonii Cufod. (Kuijt 2407, CR)

Tripodanthus acutifolius (Ruiz \& Pav.) Tiegh. (Da Costa Sacco 977, LEA; Hitchcock 20813, GH)

Tripodanthus flagellaris (Cham. \& Schltdl.) Tiegh. (Herter 1701, F)

Tristerix chodatianus (Pacz.) Kuijt (Weberbauer 5434, F)

Tristerix corymbosus (L.) Kuijt (Landrum 4444, LEA; Sargent s.n., GH)

Tristerix longebracteatus (Desr.) Barlow \& Wiens (Cuatrecasas 14661, GH; West 8158, GH; Rimbach s.n., F)

Tristerix penduliflorus Kuijt (Feverer 4054, LEA)

Tristerix peruvianus (Pacz.) Kuijt (Sagástegui A. et al. 10327, LEA)

Tristerix verticillatus (Ruiz \& Pav.) Barlow \& Wiens (Hunnewell 15692, GH; Goodspeed 23330, UC)

Tupeia antarctica Cham. \& Schltdl. (Kirk s.n., LEA) 